\title{
Estudo in vitro sobre a interação celular e vias endocíticas de papilomavírus humano (HPV) em leucócitos do sangue periférico
}

\section{VIVIAN SZULCZEWSKI}

Dissertação apresentada ao Programa de PósGraduação Interunidades em Biotecnologia USP/Instituto Butantan/IPT, para obtenção do Título de Mestre em Biotecnologia.

Área de concentração: Biotecnologia

Orientador: Dra. Aurora Marques Cianciarullo

\section{São Paulo}

2009 


\section{RESUMO}

SZULCZEWSKI, V. Estudo in vitro sobre a interação celular de papilomavírus humano em leucócitos do sangue periférico. 137 f. Dissertação (Mestrado em Biotecnologia) Instituto de Ciências Biomédicas, Universidade de São Paulo, São Paulo, 2009.

Diversos tipos de câncer são geralmente atribuídos a mutações gênicas e fatores ambientais. No caso do câncer anogenital, o papilomavírus humano (HPV) aparece como o principal agente etiológico da doença, sendo este semelhante em muitos aspectos ao papilomavírus bovino (BPV). Ao redor de 120 tipos já foram totalmente caracterizados, sendo o HPV16 e o HPV18 os vírus oncogênicos responsáveis por aproximadamente $70 \%$ de todos os cânceres cervicais. Estudos recentes evidenciaram que além da transmissão sexual do HPV, há outras formas de contágio. Entretanto, a dificuldade na obtenção de quantidades viáveis do tipo selvagem ou mutante do HPV tem limitado em muito os estudos de diversos aspectos da biologia do papilomavírus. Diversos vírus entram em células hospedeiras para sobreviver, replicar e evadir o sistema imune. Até o momento, a entrada dos HPVs e o seu tráfego pela célula hospedeira ainda não estão bem elucidados. Existem evidências de que o BPV1, o HPV16 e HPV58 são endocitados via clatrina, enquanto o HPV31 pode utilizar a endocitose dependente de caveolina ou clatrina, sugerindo assim que a entrada dos HPVs na célula hospedeira pode ser um processo complexo. Este estudo investigou a possibilidade de o HPV infectar células leucocitárias do sangue periférico humano, como parece ocorrer com BPV. Neste contexto, as proteínas L1 e L2 do capsídeo viral foram expressas em culturas de células epiteliais humanas da linhagem 293T, utilizando os vetores pUF3L1h e pUF3L2h construídos sob a regulação do promotor de citomegalovírus humano. Desenvolvemos um método simples, rápido, de baixo custo e eficiente, para a separação dos leucócitos, com preservação da morfologia e viabilidade celular, adequado às necessidades desta pesquisa. A expressão de L1 e L2 foi confirmada por Western-blot e análises ultraestruturais demonstraram que estas proteínas foram capazes de se estruturar em VPLs ("virus like particles"). Análises de imunofluorescência mostraram a expressão intracelular de L1 e L2 e a presença de epítopos conformacionais nas VLPs produzidas em células 293T. Após as interações entre as células leucocitárias do sangue de mulheres voluntárias sadias e as VLPs produzidas neste estudo, tanto as proteínas do capsídeo L1 quanto as VLPs estruturadas foram internalizadas por monócitos e linfócitos. Além disso, demonstramos a co-localização de VLPs com transferrina (Tf) e com o receptor de Tf (TfR), após 45 minutos de interação, sugerindo que as VPLs de HPV16 possam ser internalizadas pelos leucócitos através do TfR. Neste contexto, levanta-se a questão sobre o papel dos linfócitos como possíveis sítios de latência para o HPV, assim como, veículo de disseminação e transmissão viral. Concluímos que as VLPs L1L2 do HPV16 podem utilizar a via endocítica do ferro mediada por clatrina, através do complexo VLPs-Tf-TfR. Estes dados sugerem que o HPV16 pode utilizar a via alternativa de infecção Tf-TfR, permanecendo de forma latente em leucócitos. Esta porta de entrada oportunista poderia explicar a propagação crescente e alarmante deste agravo à saúde humana, motivo de preocupação nos sistemas mundiais de saúde pública. Este trabalho demonstrou pela primeira vez a internalização de VLPs L1L2 do HPV16 em leucócitos do sangue periférico humano.

Palavras-chave: Separação de leucócitos. HPV. Produção de VLP. Transferrina. Receptor de transferrina. Interação patógeno-célula hospedeira. Câncer cervical. Câncer anogenital. Alvo terapêutico. Saúde pública. 


\begin{abstract}
SZULCZEWSKI, V. In vitro study on the interaction of human papillomavirus in cell from peripheral blood leukocytes. $137 \mathrm{f}$. Dissertation (MSc in Biotechnology) - Institute of Biomedical Sciences, University of São Paulo, São Paulo, 2009.

Several types of cancer are generally attributed to gene mutations and environmental factors. In the case of anogenital cancer, the human papillomavirus (HPV) appears as the major causative agent of the disease, which is similar in many respects to bovine papillomavirus (BPV). Around 120 types have been fully characterized, with HPV16 and HPV18 the oncogenic virus responsible for about $70 \%$ of all cervical cancers. Recent studies revealed that besides the sexual transmission of HPV, there are other forms of contagion. However, the difficulty in obtaining quantities of viable wild-type or mutant of HPV is very limited in the studies of various aspects of the biology of human papillomavirus. Several virus enter host cells to survive, replicate and evade the immune system. So far, the entry of HPV and its traffic by the host cell are still not well elucidated. There is evidence that the BPV1, HPV16 and HPV58 are internalized in a way clathrin-mediated while HPV31 can use the dependent endocytosis of caveolin or clathrin, suggesting that the entry of HPV in the host cell can be a complex process. This study investigated the possibility of HPV infect the cells of peripheral blood leukocyte humans, as seems to occur with BPV. In this context, the L1 and L2 viral capsid proteins were expressed in human epithelial cell line 293T cultures, using the vectors pUF3L1h and pUF3L2h constructed under the regulation of the promoter of human cytomegalovirus. We developed a simple, fast, inexpensive and efficient method for the separation of leukocytes, with preservation of cell viability and morphology, appropriate to the needs of this research. The expression of L1 and L2 was confirmed by Western-blot and ultrastructural analysis showed that these proteins were able to structure on VPLs ("virus like particles"). Immunofluorescence analysis showed the expression of intracellular L1 and L2, as well as the presence of conformational epitopes in VLPs produced in 293T cells. After the interactions between leukocyte cells of the blood from healthy women volunteers and VLPs produced in this study, both the L1 capsid protein structured as the VLPs were internalized by monocytes and lymphocytes. Moreover, our results demonstrated the colocalization of VLPs with transferrin (Tf) and the receptor of $\mathrm{Tf}$ (TfR), after 45 minutes of interaction, suggesting that the VPLs of HPV16 can be internalized by leukocytes via the TfR. In this context, there is the question on the role of lymphocytes as possible sites of latency for HPV, as well as vehicle for dissemination and viral transmission. We conclude that the VLPs L1L2 of HPV16 may use the iron endocytic pathway mediated by clathrin through the complex VLPs-Tf-TfR. These data are suggesting that HPV16 can use the alternative route of infection Tf-TfR and to remain in latent form into leukocytes. This port of entry opportunist could explain the growing and alarming spread of this disease to human health, cause for concern in the global public health. This study showed for the first time the internalization of VLPs L1L2 of HPV16 in human peripheral blood leukocytes.
\end{abstract}

Keywords: Leukocytes separation. HPV. VLP production. Transferrin. Transferrin receptor. Pathogen-host cell interaction. Cervical câncer. Anogenital câncer. Therapeutic target. Public health. 


\section{INTRODUÇÃ̃o}

\subsection{O Papilomavírus Humano}

\subsubsection{O Papilomavírus Humano como agente etiológico do câncer anogenital}

A infecção por certos papilomavírus humanos (HPV) representa o maior fator de risco para o desenvolvimento do câncer anogenital, atualmente reconhecido como o principal agente etiológico desta doença sexualmente transmissível (DST) (ZUR HAUSEN, 2002). Este fato torna os parceiros sexuais altamente comprometidos com a infecção e transmissão do HPV, à semelhança do que ocorre com o HIV (vírus da imunodeficiência humana).

Os HPVs são vírus mucoepteliotrópicos que infectam a camada basal da mucosa e do epitélio queratinizado. Ao infectar o homem são capazes de causar tumores verruciformes, benignos ou malignos, em tecidos como pele, boca, laringe, ânus, colo do útero e genitália feminina e masculina. São vírus altamente espécie-específicos e, mesmo apresentando uma estrutura genômica muito semelhante, cada tipo de HPV infecta regiões específicas do corpo humano (BOCCARDO et al., 2003).

A transmissão ocorre pelo contato entre pele e mucosa, em qualquer região do corpo, através de pequenas abrasões dos tecidos. No caso de lesões anogenitais a transmissão ocorre preferencialmente durante a atividade sexual. O contágio perinatal e fômites são vias consideradas prováveis (FREGA et al., 2003). A transmissão intra-útero fetal pode ser causada pela ascensão da infecção através do canal cervical infectado (via transcervical) ou hematologicamente pela placenta (via hematogênica). Dados da literatura científica indicam a presença de DNA do HPV no fluido amniótico (ARMBRUSTER-MORAES et al.,1994; XU et al., 1998), membranas fetais (WANG et al., 1998), células trofoblásticas placentárias, no trato orofaringeano de crianças nascidas através de parto cesariano (FAVRE et al., 1998; PURANEN et al., 1997; XU et al., 1998; WANG et al., 1998), bem como em material de aborto espontâneo (HERMONAT et al., 1997). 
Os Papilomavírus representam um grupo complexo de viroses patogênicas humanas. Em torno de 120 tipos já foram totalmente caracterizados. Entre estes, alguns tipos específicos estão reconhecidamente relacionados com o trato anogenital (DE VILLIERS et al., 2004). Os HPVs identificados que infectam a mucosa anogenital podem ser classificados conforme o seu potencial para o desenvolvimento de lesões neoplásicas (Tabela 1).

O grupo considerado de alto risco está constantemente associado com o câncer anogenital e lesões pré-cancerosas, chamadas de Neoplasias Intraepteliais Cervicais (NICs), sendo que os HPVs 16 e 18 são responsáveis por 70\% dos casos de câncer cervical. Os HPVs de baixo risco oncogênico podem causar lesões chamadas de condilomas nas genitálias femininas e masculinas (MUÑOZ et al., 2006). Nestas lesões, aproximadamente $90 \%$ dos casos estão associados à infecção pelos HPVs tipos 6 e 11 (STEBEN; DUARTE-FRANCO et al., 2007).

Tabela 1: Classificação dos tipos de HPV.

Grupo Tipo de HPV

Alto Risco $16,18,31,33,35,39,45,51,52,56,58,59$

Potencialmente de alto risco $26,53,66,68,73,82$

Baixo risco 6, 11, 40, 42, 43, 44, 54, 61, 70, 72, 81, CP6108

Adaptado de Muñoz et al., 2006. 


\subsubsection{Epidemiologia}

Anualmente, são estimados ao redor de 500.000 novos casos de câncer cervical em todo o mundo, dos quais $80 \%$ ocorrem nos países em desenvolvimento (CUTTS et al., 2007). Embora seja uma neoplasia passível de prevenção devido à sua progressão lenta e de fácil detecção, o câncer cervical leva a óbito mais de 200.000 mulheres por ano (BOSCH et al., 2002). Trata-se de infecção altamente prevalente, detectada em $10 \%$ a $20 \%$ da população sexualmente ativa entre 15 e 49 anos de idade, inclusive em mulheres assintomáticas (NONNENMACHER et al., 2002). Estima-se que 50\% das pessoas sexualmente ativas irão adquirir uma infecção pelo HPV ao longo de suas vidas, sendo que para as mulheres até os 50 anos de idade esta proporção sobe a $80 \%$.

Segundo a Organização Mundial da Saúde (OMS), em todo o mundo, aproximadamente $12 \%$ dos casos de câncer na mulher são causados pelo HPV. Estudos epidemiológicos sugerem que em $99,7 \%$ dos casos totais de câncer cervical foi detectado o DNA viral de HPVs.

No Brasil, o HPV tem sido responsável por até $91 \%$ dos casos de câncer cervical (RABELO-SANTOS et al., 2003). De acordo com o Instituto Nacional do Câncer (INCA), são esperados para o Brasil no ano de 2008, 18.680 novos casos de câncer de colo do útero, onde a taxa de risco estimada é de 19 casos a cada 100 mil mulheres.

Apesar da alta prevalência, a maioria das infecções não ocasiona o surgimento de sintomas e/ou lesões visíveis. Conforme o National Câncer Institute, dos Estados Unidos da América (USA), em um curto período de tempo, aproximadamente $90 \%$ das mulheres infectadas pelo HPV eliminam o vírus pela ação do sistema imune, enquanto que em um pequeno número de mulheres a infecção é persistente por anos. A persistência da infecção por HPVs de alto risco eleva muito o risco do desenvolvimento e progressão de lesões neoplásicas no trato anogenital (SCHLECHT et al., 2001).

Estudos recentes correlacionam o câncer de pênis e ânus com o HPV, com predominância do HPV 16 e HPV 18 (BEZERRA et al., 2001; BJORGE et al., 2002). Parece existir um risco maior deste tipo de câncer em companheiros de mulheres portadoras de câncer cervical, sendo que nas próprias mulheres o ânus representa o sítio de maior risco de ocorrência de um segundo evento neoplásico (HEMMINKI et al., 2000; RUBIN et al., 2001). 
Por outro lado, há relatos de casos de câncer anal em homens e mulheres que nunca mantiveram relacionamento sexual anal. Este fato levanta suspeita sobre a existência de outras vias de infecção pelo HPV, considerado um problema sério de saúde pública, da magnitude do HIV. Esta situação agrava-se ainda mais diante da possibilidade destas partículas virais veicularem em células do sangue periférico humano, conforme observado em bovinos, com respeito às partículas BPV (CARVALHO, 2003; STOCCO DOS SANTOS et al., 1998).

Sabe-se que algumas populações investigadas diferem em incidências de vários fatores de risco para infecções pelo HPV. Dentre os fatores de risco clássicos, destacam-se: vida sexual ativa precoce, promiscuidade, alta paridade, baixa faixa etária, tabagismo e baixo nível sócio-econômico, sendo os dois primeiros os fatores mais consistentes (BAUER et al., 1993; FRANCO et al., 2001; HILDESHEIM et al., 1993). Existem outros fatores de risco considerados menores, como uso prolongado de anticoncepcional oral (SCHIFFMAN et al., 1995; WORLD HEALTH ORGANIZATION, 1993), deficiências nutricionais (BUTTERWORTH et al., 1992), a infecção pelo HIV (HO et al., 1994; MATORRAS et al., 1991) e outras infecções genitais causadas por agentes sexualmente transmissíveis como a Chlamydia trachomatis e o Herpes simples (FRANCO, 1991; NONNENMACHER et al., 2002).

Segundo os dados analisados nos USA, entre 1990 e 2004, calculou-se que anualmente os custos médicos associados com a prevenção e tratamento de verrugas anogenitais e doenças relacionadas ao HPV ficaram em torno de quatro bilhões de dólares. No entanto, o estudo não conseguiu identificar perdas de produtividade no trabalho, resultado do tempo gasto recebendo cuidados médicos, morbidez ou mortalidade, o que subiria provavelmente para pelo menos cinco bilhões de dólares por ano (INSIGA et al., 2005). Dados estatísticos referentes ao fardo econômico anual associado com a prevenção e o tratamento de doenças relacionadas ao HPV na população ainda não estão disponíveis no Brasil. 


\subsubsection{Biologia do Papilomavírus Humano}

Os HPVs são vírus pertencentes à família Papillomaviridae. De acordo com o Centro de Referência para Papilomavírus, DKFZ, Heidelberg, Alemanha, os HPV16 e HPV18 pertencem ao gênero Alpha-Papillomavirus (DE VILLIERS et al., 2004). São pequenos vírus de DNA dupla fita circular, desprovidos de envelope. Consistem de um capsídeo icosaédrico de aproximadamente $55 \mathrm{~nm}$ de diâmetro formado por 72 capsômeros, o qual é composto por duas proteínas estruturais L1 e L2 (Fig. 1A) (BURD, 2003; GNANAMONY et al., 2007).

O genoma dos HPVs é formado por aproximadamente 8.000 pares de bases associadas com histonas, organizadas num minicromossomo, constituído por uma região regulatória não traduzida "long control region" (LCR) e genes que codificam seis proteínas precoces, denominadas E1, E2, E4, E5, E6 e E7 (E:“Early”), e duas proteínas tardias, L1 e L2 (L: "Late") (Fig. 1B).

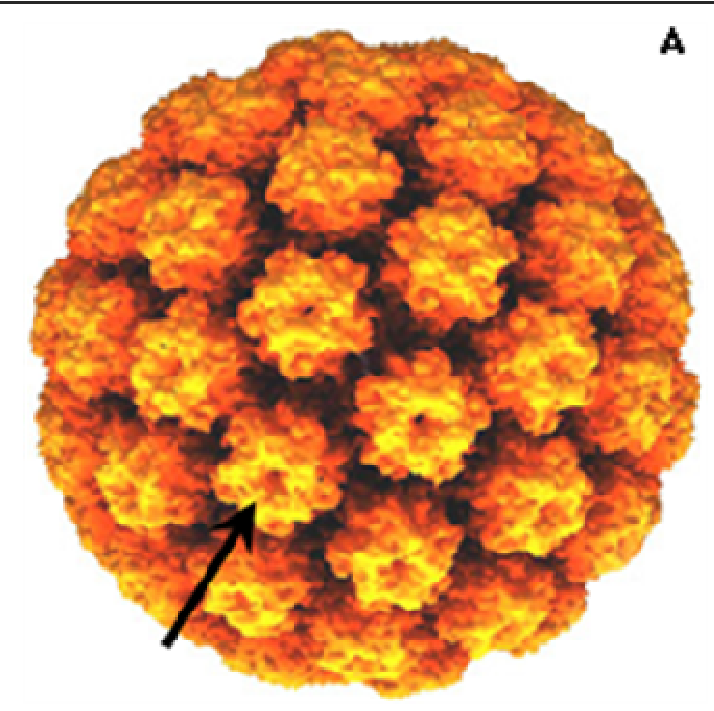

Pentâmero de L1

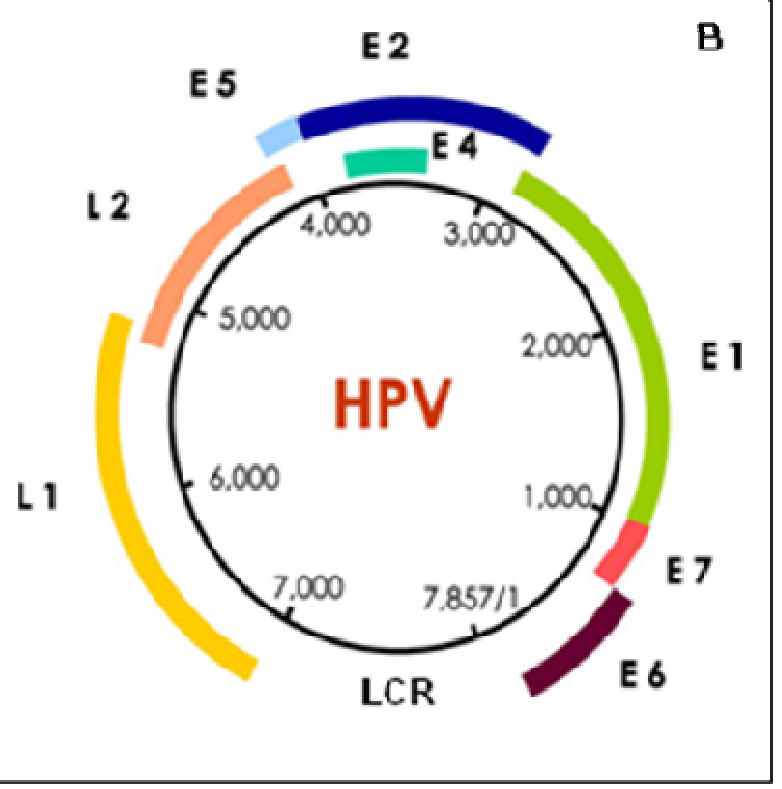

Figura 1: Representação esquemática do HPV e do genoma viral destes vírus. (A) Modelo atômico do capsídeo icosaédrico formado por 72 capsômeros (http://microbiologybytes.wordpress.com/2006/10/23/). (B) Representação esquemática do genoma do HPV, constituído por genes que codificam proteínas precoces (E:"Early"), proteínas tardias (L: "Late") por uma região regulatória não traduzida (LCR). Adaptado de Muñoz et al., 2006. 
As proteínas E1, E2, E4, E5, E6 e E7 desempenham diversas funções no ciclo de vida do papilomavírus humano (Tabela 2). As primeiras proteínas a serem expressas são E1 e E2 e estão envolvidas na replicação viral e transcrição celular. E1 possui atividade de helicase dependente de ATP (adenosina tri-fosfato), necessária na replicação do genoma viral (WILSON et al., 2002). E2 forma um complexo com E1 facilitando sua ligação à origem de replicação viral. Além disso, E2 atua como um fator de transcrição regulando a expressão dos genes virais E6 e E7 (CRIPE et al., 1987). Em baixos níveis E2 age como ativador transcricional, enquanto que em altos níveis reprime a expressão de genes virais (STEGER et al., 1997).

O papel de E4 ainda não está muito claro. Sabe-se que é formada por “splincing” de sequências de RNA que codificam os cinco primeiros aminoácidos de E1 com a janela de leitura de $\mathrm{E} 4$, formando transcritos $\mathrm{E} 1^{\wedge} \mathrm{E} 4$. Esta proteína parece associar-se à rede de citoqueratina celular, o que sugere seu envolvimento na maturação e liberação de vírions para o meio extracelular (HEBNER; LAIMINS, 2006).

E5 é uma proteína de membrana hidrofóbica encontrada preferencialmente no complexo de Golgi. Associa-se sua interação com receptores de fatores de crescimento, auxiliando a transformação celular no início da tumorigênese (HEBNER; LAIMINS, 2006). Além disso, a presença de E5 nas células hospedeiras pode alterar a apresentação de antígenos celulares, como diminuir a expressão de moléculas de HLA ("human leukocyte antigen" antígeno de leucócito humano) de Classe I (ASHRAFI et al., 2005) e modificar a expressão na superfície de moléculas MHC ("major histocompatibility complex" - complexo principal de histocompatibilidade) de Classe II (ZHANG et al., 2003).

E6 e E7 atuam modulando a atividade de proteínas celulares que regulam o ciclo celular, como p53 e pRB, respectivamente. A proteína E6 dos HPVs de alto risco é formada por aproximadamente 150 aminoácidos, sendo localizadas no núcleo e citoplasma de queratinócitos infectados pelo HPV, apresentando dois motif zinc finger (HEBNER; LAIMINS, 2006). Uma das funções mais bem caracterizadas de E6 é a sua capacidade de interferir com p53. O produto do gene p53 é uma proteína supressora tumoral envolvida nos processos de reparo do DNA e apoptose. E6 liga-se a proteína p53 através de uma proteína ubiquitina-ligase, a E6-AP. A formação deste complexo resulta na degradação de p53, que, por sua vez, perde o controle da transição de G1/S e G2/M, e com isso, torna-se susceptível a instabilidade cromossômica, com consequências mutacionais para as células HPV-positivas 
(THOMAS et al., 1999). Outro papel importante de E6 é a interação com proteínas da família PDZ, as quais envolvem funções de sinalização e adesão celular. E6, ainda, pode ativar a telomerase em células infectadas, o que permite manter o comprimento dos telômeros em células epiteliais (HEBNER; LAIMINS, 2006).

E7 é uma fosfoproteína que contém em torno de 98 aminoácidos, apresenta três regiões bem conservadas CR1, CR2 e CR3 e está localizada principalmente no núcleo das células infectadas. O domínio CR1 compreende a região amino-terminal, CR2 contém um motif LXCXE, que faz a ligação entre E7 e membros da família da proteína supressora tumoral retinoblastoma (pRB), e CR3 consiste de dois motif zinc finger (HEBNER; LAIMINS, 2006). No ciclo de vida do HPV, uma das principais funções estudadas de E7 é a interação com a família de proteínas $\mathrm{RB}$, a qual participa da regulação do ciclo celular. $\mathrm{Na}$ forma hipofosforilada, pRB controla a progressão da fase G1 para fase S, através da ligação com o fator de transcrição E2F, que, por sua vez, é impedido de ativar a transcrição de muitos componentes envolvidos na síntese de DNA (CID-ARREGUI et al., 2003; GNANAMONY et al., 2007; MCLAUGHLIN-DRUBLIN et al., 2005; SUBRAMANYAM; KRISNA, 2006; WILSON et al., 2005).

Vale lembrar que as linhagens celulares originadas a partir de carcinomas cervicais expressam E6 e E7 de forma constitutiva, as quais são necessárias para manutenção do fenótipo transformado (GOODWIN; DIMAIO, 2000). Assim, devido às interações com diversos alvos celulares, E6 e E7 indicam sua importância funcional para o crescimento de células cancerosas, exercendo um papel fundamental nos mecanismos oncogênicos do HPV. E embora não sejam as únicas responsáveis, estas proteínas estão diretamente envolvidas nos processos de transformação e imortalização celular induzidos por este vírus, cujas vias ainda não são bem compreendidas (HEILMAN et al., 2009).

As proteínas L1 e L2 são expressas tardiamente no ciclo reprodutivo do vírus. Até o momento, as evidências sugerem que os epítopos de neutralização imunodominantes estão localizados na proteína L1. Já L2 parece contribuir na encapsidação do DNA viral (HOLMGREN et al., 2005; ZHOU et al., 1993) e reforçar a infectividade do HPV (RODEN, et al., 2001). Estima-se a razão de 1:30 moléculas L2 e L1, respectivamente, compondo o capsídeo viral (CHEN et al., 2000). 
Tabela 2: Revisão dos produtos dos genes do HPV.

\begin{tabular}{|c|c|}
\hline $\begin{array}{l}\text { Produto } \\
\text { do gene }\end{array}$ & Descrição \\
\hline E1 & $\begin{array}{l}\text { Atividade de helicase dependente de ATP; necessária para a replicação viral } \\
\text { e controle da transcrição gênica. }\end{array}$ \\
\hline $\mathrm{E} 2$ & $\begin{array}{l}\text { Fator de transcrição viral; necessária para a replicação viral e controle da } \\
\text { transcrição gênica. }\end{array}$ \\
\hline $\mathrm{E} 4$ & $\begin{array}{l}\text { Parece interagir com a rede de citoqueratina celular; sugere-se seu } \\
\text { envolvimento na montagem viral. }\end{array}$ \\
\hline E5 & $\begin{array}{l}\text { Pode interagir com receptores de fatores de crescimento; pode diminuir a } \\
\text { expressão de moléculas de HLA de Classe I e alterar a expressão na } \\
\text { superfície de moléculas MHC de Classe II. }\end{array}$ \\
\hline E6 & $\begin{array}{l}\text { Envolvida no processo de transformação e imortalização celular; degrada } \\
\text { p53; pode ativar a telomerase; efeito anti-apoptótico; induz a instabilidade } \\
\text { genômica. }\end{array}$ \\
\hline E7 & $\begin{array}{l}\text { Envolvida no processo de transformação e imortalização celular; interação } \\
\text { com pRB; induz a instabilidade genômica. }\end{array}$ \\
\hline L1 & Principal proteína do capsídeo. \\
\hline $\mathrm{L} 2$ & $\begin{array}{l}\text { A proteína viral menos abundante; contribui na encapsidação do DNA viral; } \\
\text { envolvida no transporte nuclear do DNA viral. }\end{array}$ \\
\hline
\end{tabular}

Adaptado de Boulet et al., 2007. 


\subsubsection{Ciclo de vida do HPV e a resposta imune à infecção viral}

Os papilomavírus são organismos obrigatoriamente intracelulares, perfeitamente adaptados ao tecido do seu hospedeiro natural e dependentes da maquinaria celular (MUNÕZ et al., 2006). O ciclo de vida do HPV está diretamente ligado à diferenciação epitelial (Fig. 2). Inicialmente, por meio de abrasões ou microlesões na pele ou mucosas, os HPVs infectam células pouco diferenciadas do compartimento basal dos epitélios estratificados. As células da camada basal são capazes de se dividir constantemente, e após a divisão, as células filhas migram para o compartimento suprabasal para finalizar a diferenciação. Em condições normais estas células perdem a atividade metabólica (WATT, 1998).

Após a penetração do vírus nas células, acredita-se que o genoma do HPV se hospede no núcleo, sob a forma epissomal, e ative o promotor de transcrição dos genes precoces. Neste momento, inicia-se a replicação do DNA viral com aproximadamente 50 a 100 cópias por célula. À medida que a célula hospedeira se divide, o genoma viral é distribuído entre as células filhas. Estas podem migrar para as camadas superiores do epitélio e dar início ao processo de diferenciação. As proteínas virais expressas estimulam a manutenção do ciclo celular ativo das células infectadas durante o processo de diferenciação (STUBENRAUCH; LAIMINS, 1999). A partir deste estágio, o promotor de genes tardios, que codifica as proteínas estruturais L1 e L2, é ativado. Inicia-se, então, a fase produtiva do ciclo de vida viral, a qual as células suprabasais são reprogramadas pelo vírus para amplificar o número de cópias do genoma do HPV. O empacotamento do DNA viral em novos capsídeos ocorre apenas nas células mais diferenciadas, onde a progênie do vírus é liberada da célula (Fig. 2) (OZBUN et al., 2002; STUBENRAUCH; LAIMINS, 1999).

O HPV pode ser encontrado em amostras cervicais na forma epissomal, integrado ou mista, com ambas as formas. O evento de integração do DNA viral frequentemente ocorre com o rompimento da região precoce E1-E2, sendo o gene viral E2 o sítio preferencial desta integração (BAKER et al., 1987). Como o produto do gene E2 controla a transcrição das proteínas virais E6 e E7, seu rompimento leva à desregulação da expressão destas proteínas (Fig. 2). As transcrições derivadas de DNA viral integrado são mais estáveis do que os derivados da forma epissomal. Acredita-se que a integração do HPV16 proporcione uma 
vantagem de crescimento seletivo nas células infectadas, aumentando as chances de progressão de lesões de alto grau e carcinomas invasivos (WOODMAN et al., 2007).

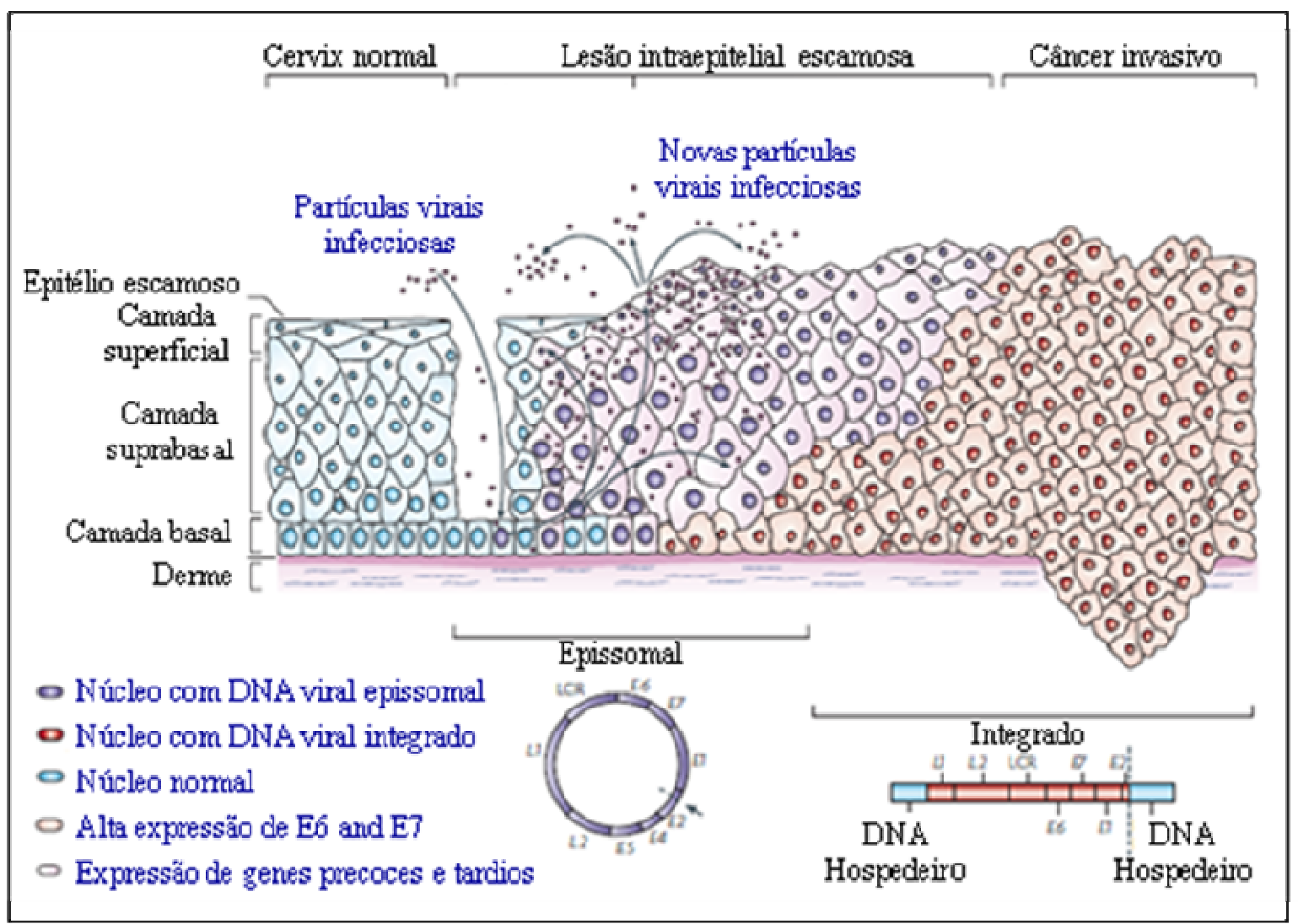

Figura 2: O ciclo de vida do HPV e a integração do genoma viral. Os HPVs infectam as células da camada basal do epitélio através de microlesões. Após a infecção, os genes precoces E1, E2, E4, E5, E6 e E7 são ativados e o DNA viral é replicado. Nas camadas mais superiores do epitélio, o número de cópias do genoma viral é amplificado e as proteínas estruturais são expressas. L1 e L2 encapsidam o DNA viral, as novas partículas virais são liberadas na superfície epitelial e podem infectar novas células. Infecções por HPVs de alto risco podem progredir para neoplasias intraepteliais cervicais (NIC). Quando não tratadas, estas lesões podem evoluir para um câncer invasivo, o qual está associado com a integração do DNA viral ao genoma hospedeiro. O sítio preferencial desta integração é o gene viral E2. Adaptado de Woodman et al., 2007.

Os HPVs são agentes infecciosos bem sucedidos, os quais evoluíram para evitar ao máximo a sua exposição ao sistema imune hospedeiro. No entanto, o sistema imune tem um papel importante no controle das infecções por HPV (ZUR HAUSEN, 2002). Existem evidências de que os mecanismos imunes inatos e adaptativos, mediados por resposta imune 
humoral e celular contra anticorpos do HPV, estão relacionados à regressão de lesões causadas por infecções pelo HPV (ZUR HAUSEN, 2002). Isto pode ser observado em estudos com indivíduos imunossuprimidos, nos quais ocorre um aumento na incidência e persistência prolongada de infecções por HPV (GNANAMONY et al., 2007; ZUR HAUSEN, 2002). Como mencionado anteriormente, em torno de $70 \%$ das mulheres eliminam a infecção em torno de 12 meses, o qual indica um papel efetivo do sistema imune em eliminar o vírus (GNANAMONY et al., 2007).

$\mathrm{Na}$ maioria dos indivíduos infectados pelo HPV, os anticorpos neutralizantes gerados são direcionados contra epítopos conformacionais do capsídeo L1. No entanto, após uma infecção, baixos títulos de anticorpos são produzidos contra o HPV (VILLA et al., 2005), refletindo a ausência de viremia. Além disso, o tempo da soroconversão é lento, ocorrendo apenas em torno da metade das pessoas expostas.

Diversas estratégias são aplicadas pelo papilomavírus para escapar do sistema imune. A replicação e montagem viral ocorrem em tempo suficiente para que os queratinócitos basais sofram diferenciação completa e descamação. Sendo assim, não há indução de morte citopática ou necrose celular, consequentemente ausência de resposta inflamatória importante para ativação do sistema imune. Outros estudos demonstram que as proteínas virais interferem nas respostas do sistema imune. Por exemplo, E7 promove uma alteração na expressão dos genes induzidos por interferon I, $\alpha$ e $\beta$ e E6 inibe a expressão de interleucina-18. Além disso, a proteína do capsídeo L1 só é expressa tardiamente na fase produtiva do vírus e em baixos níveis (STANLEY et al., 2008). 


\subsubsection{Proteínas do capsídeo L1 e L2 e Virus Like Particles (VLPs)}

As dificuldades em obter estoques de vírions infecciosos do HPV complicam os estudos de diversos aspectos da biologia do papilomavírus, como a definição de epítopos neutralizantes e interações entre célula hospedeira e vírus. Lesões induzidas por HPVs, principalmente os tipos de alto risco, apresentam pequenas quantidades de partículas virais infecciosas (CHRISTENSEN et al., 1996). Visando superar estas barreiras, diversos sistemas de culturas celulares vem sendo desenvolvidos, de modo que quantidades viáveis sejam obtidas, possibilitando os estudos básicos sobre o papilomavírus e o desenvolvimento de vacinas profiláticas.

O capsídeo do papilomavírus é formado por duas proteínas estruturais, L1 caracterizada como proteína principal do capsídeo, altamente conservada entre os diferentes tipos de papilomavírus, e L2. Acredita-se que sua localização está associada com os vértices dos pentâmeros nos capsômeros (ZUR HAUSEN, 1996). Em L1, a massa molecular corresponde aproximadamente a $55 \mathrm{kDa}$ ( 510 aminoácidos), representando em média 80\% do total de proteína viral. A massa molecular de L2 é em torno de 50 kDa ( 470 aminoácidos. No entanto, ela migra em géis de SDS-poliacrilamida entre 70 a $80 \mathrm{kDa}$ (BELNAP et al., 1996; MÜLLER et al., 1995). Há uma semelhança estrutural notável entre o BPV-1 e o HPV1, o capsídeo é formado por 72 projeções de capsômeros ( $\mathrm{T}=7$ ) (Fig. 3C) côncavos e dispostos radialmente numa altura máxima de 5,8 $\mathrm{nm}$. Um canal cilíndrico, com em torno de 2,8 nm de diâmetro, estende-se ao longo do eixo de cada capsômero a partir do interior do vírus. O sistema de contato intercapsômeros é indistinguível entre BPV-1 e HPV-1, sugerindo que a estrutura do capsídeo destas partículas virais seja bem conservada evolutivamente (BAKER et al., 1991; MODIS et al., 2002).

O gene L1 pode ser expresso em diferentes sistemas de expressão, como levedura (BAZAN et al., 2007a,b; SASAGAWA et al., 1995), bactéria (AIRES et al., 2006; NARDELLI-HAEFLIGER et al., 1997), plantas (WARZECHA et al., 2003), inseto (KIRNBAUER et al., 1992; MÜLLER et al., 1997) e em células de mamíferos (CIANCIARULLO et al., 2007, 2008; KUCK et al., 2006; MOSSADEGH et al., 2004; PYEON et al., 2005), conduzindo à formação de VLPs ("Vírus-Like Particles"), propriedade esta intrínseca a alta expressão de L1. In vitro, as VLPs, compostas por L1 isoladas ou em 
conjunto com L2, assemelham-se em muito aos vírions, apenas desprovidos do genoma viral (Fig. 3D). No entanto, a coexpressão de L1 e L2 parece aumentar a eficiência da formação e estabilidade das VLPs (MÜLLER et al., 1997).

A estrutura atômica de L1 do HPV16 foi determinada cristalograficamente a partir de uma pequena VLP (“small VLPs"), composta por 12 pentâmeros e rica em estruturas $\alpha$ hélices (Fig. 3A e B).

A síntese de L2 parece preceder a expressão de L1 em queratinócitos em diferenciação terminal. Além disso, L2 é translocada para o núcleo independente de L1 (KIEBACK; MÜLLER, 2006). Embora a proteína L2 seja dispensável para a formação dos capsídeos, existem evidências de que a sua presença é essencial para a completa produção de pseudovírions e vírions infecciosos de HPV, visto que L2 parece reforçar a infectividade deste vírus (BUCK et al., 2008; HOLMGREN et al., 2005; RODEN, et al., 2001). Acredita-se ainda que L2 possa facilitar a montagem de capsômeros de L1 purificado, onde apenas uma pequena porção de L2 fica exposta na superfície dos capsídeos maturos (BUCK et al., 2008). 


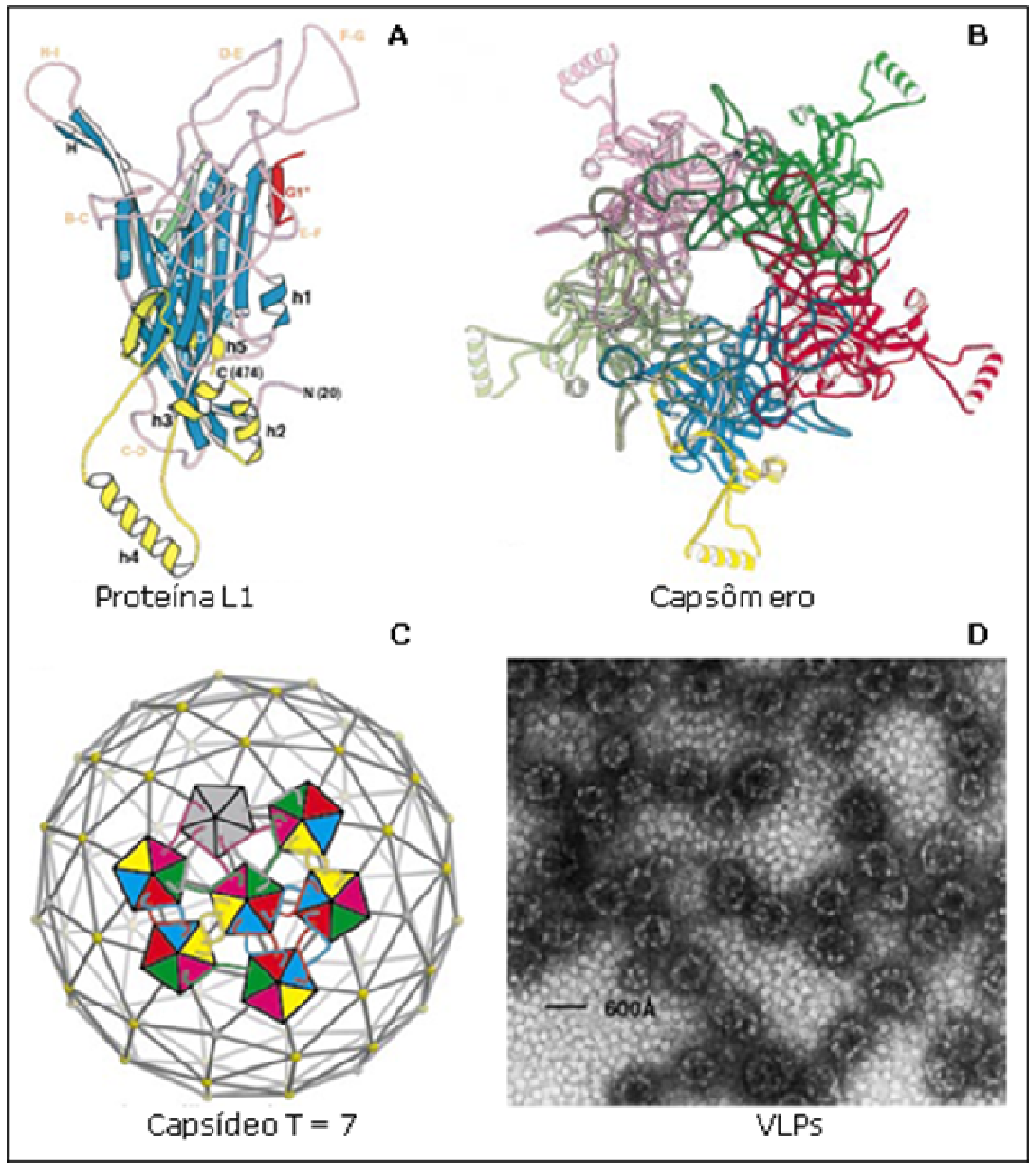

Figura 3: Representação estrutural dos monômeros, capsômeros e VLPs de L1 de HPV16. (A) Monômero e (B) capsômero de L1. Adaptado de Chen et al., 2000. (C) Diagrama do capsídeo completo, formado por 72 projeções de capsômeros ( $\mathrm{T}=7)$. Adaptado de Modis et al., 2002. (D) Microscopia eletrônica de VLPs de L1 produzidas in vitro, após expressão da proteína em Escherichia coli. Adaptado de Chen et al., 2000. 


\subsubsection{Vacinas contra o HPV}

Em geral, o controle do câncer cervical está baseado em sistemas de triagens citopatológicas, como exame de Papanicolaou, capaz de reduzir substancialmente os casos de câncer nos países em que as triagens são eficientes. No entanto, nos países em desenvolvimento, estes sistemas são ineficientes e com elevado custo aos órgãos de saúde pública e privada. Novos testes vêm sendo desenvolvidos para aumentar a eficiência na detecção de neoplasias intraepiteliais cervicais de alto risco, como NIC-2/NIC-3 (WONG et al., 2009). Apesar das vacinas também representarem um custo efetivo na prevenção e no tratamento de doenças, é uma estratégia prioritária o desenvolvimento de vacinas eficazes contra o HPV, visto que a vacinação em massa da população poderá reduzir drasticamente a incidência e mortalidade causada pelo vírus.

As oncoproteínas E6 e E7 dos HPVs de alto risco transformaram-se em alvos de pesquisa para estratégias imunoterápicas e para o desenvolvimento de vacinas que visam o controle e a regressão de lesões associadas ao HPV. Estas vacinas de DNA tornam-se atraentes por gerarem imunoterápicos antígeno-específicos, com capacidade de estimular o sistema imune e, ainda, por sua simplicidade, estabilidade, segurança, e capacidade para administrações repetidas (BIBANCOS et al., 2006a,b; PENG et al., 2004; RODEN et al., 2004).

Atualmente, as vacinas mais promissoras são as profiláticas, baseadas principalmente na indução de anticorpos neutralizantes contra a proteína L1 do capsídeo, sob a forma de VLPs ou capsômeros, capazes de inibir a entrada do vírus na célula hospedeira (VILLA et al., 2005, 2006a). As VLPs de L1 são capazes de induzir anticorpos neutralizantes sistêmicos e de mucosa e, ainda, induzir anticorpos protetores nos animais imunizados (LIU et al., 1998; REUTER et al., 2003).

Propostas de vacinas profiláticas baseadas na proteína L2 do capsídeo do HPV também estão em desenvolvimento, visto que, L2 possui regiões altamente conservadas em diferentes genótipos deste vírus. A vacinação com L2 pode fornecer imunidade a papilomavírus homólogos. No entanto, apresenta baixos títulos de anticorpos neutralizantes, quando comparados com os títulos obtidos de anticorpos específicos contra L1 (CHANDRACHUD et al., 1995; CHRISTENSEN et al., 1991; EMBERS et al., 2002). 
Estudos utilizando peptídeo ou proteína L2 demonstraram induzir anticorpos de neutralização cruzada contra diferentes tipos de HPV, entre os quais HPV6, 16, 18 e 31. Entretanto, não está clara a eficácia de neutralização desses anticorpos (PASTRANA et al., 2005).

A ocorrência de infecções com múltiplos tipos de HPV parece estar relacionada com a idade e com anormalidades citológicas. A coinfecção viral pode ter implicações no desenvolvimento de vacinas, uma vez que a imunidade conferida por elas é tipo-específica (ROUSSEAU et al., 2003). As atuais vacinas profiláticas aprovadas pela OMS, FDA ("Food na Drug Administration") e pela ANVISA (Agência Nacional de Vigilância Sanitária) no Brasil, produzidas em células de levedura (Saccharomyces cerevise) pela Merck Sharp \& Dohme contra o HPV6, 11, 16 e 18, e a vacina elaborada pela Glaxo Smith Kline (GSK) contra o HPV16 e 18 em células de insetos (Spodoptera frugiperda) utilizam partículas sintetizadas in vitro através da expressão da proteína do capsídeo L1. Ambas são produzidas a partir dos tipos virais mais prevalentes, destituídas de material genético viral, sendo desencadeadoras de resposta imunológica com altos títulos de proteção contra o vírus de origem. A vacina tetravalente apresentou em torno de $90 \%$ de eficácia contra as infecções persistentes e $100 \%$ de proteção contra neoplasias intraepteliais cervicais (NICs) do HPV6, 11, 16 e 18 (VILLA et al., 2005). Já a vacina bivalente demonstrou a proteção de $95 \%$ contra infecções persistentes e NICs do HPV16 e 18 (HARPER et al., 2006).

Em um estudo clínico, foi demonstrada a eficácia e imunogenicidade da vacina tetravalente a longo prazo. As mulheres vacinadas foram acompanhadas durante cinco anos e nenhum caso de displasias cervicais pré-cancerosas ou verrugas genitais foi observado, assim como, houve uma redução de $96 \%$ na incidência de infecções persistentes pelo HPV6, 11, 16 e 18. Além disso, durante estes cinco anos, os títulos de anticorpos induzidos pela vacina se mantiveram iguais ou acima aos obtidos por uma infecção natural (VILLA et al., 2006b).

Novas vacinas profiláticas contra o HPV16 estão em desenvolvimento no Instituto Butantan, em São Paulo, com o objetivo de atender amplamente a população por um custo reduzido ao orçamento público. As vacinas disponíveis atualmente são eficientes, pois são capazes de imunizar todas as faixas etárias simultaneamente. No entanto, estas são importadas e onerosas, fato este que impossibilita a vacinação em massa (AIRES et al., 2006a,b; BAZAN et al., 2007a,b, 2008). 


\subsection{Sangue periférico humano}

O sangue é um tecido conjuntivo líquido circulante, constituído por uma massa heterogênea de células diferenciadas, onde os elementos figurados compõem de 40 a $50 \%$ do sangue, os quais estão suspensos na fase líquida chamada de plasma.

Os principais componentes do sangue desempenham diversas funções entre si e estão subdivididos em:

a) glóbulos vermelhos também conhecidos como hemácias ou eritrócitos: são responsáveis por transportar oxigênio dos pulmões aos tecidos periféricos. Os eritrócitos normais são células anucleadas em forma de disco bicôncavo, seu diâmetro varia de 7,5 a 8,7 $\mu \mathrm{m}$ e o seu principal constituinte citoplasmático é a hemoglobina, responsável por sua característica acidófila. O número de hemácias no sangue depende do sexo. Por sua vez, os homens apresentam um número maior de células. Em homens adultos normais o número de eritrócitos no sangue circulante está entre 4,9 e 5,5 milhões por $\mathrm{mm}^{3}$, enquanto as mulheres apresentam entre 4,4 e 5 milhões por $\mathrm{mm}^{3}$ (GUYTON, 2006; STEVENS; LOWE, 1995);

b) glóbulos brancos ou leucócitos: são células móveis especializadas na defesa do organismo, combatendo vírus, bactérias e outros agentes invasores que penetram no corpo, auxiliando na remoção de tecidos lesados ou mortos. Um ser humano adulto normal possui entre 4.500 e 11.000 leucócitos por $\mathrm{mm}^{3}$ de sangue. Ao nascimento, uma criança contém em média 20.000 leucócitos por $\mathrm{mm}^{3}$ de sangue, este número vai decrescendo e aos 12 anos atinge os valores do adulto. São compostos por cinco tipos celulares que serão explorados melhor na seção 1.2.1 (ABBAS; LICHTMAN, 2005; GUYTON, 2006; STEVENS; LOWE, 1995);

c) plaquetas ou trombócitos: participam do processo de coagulação sanguínea. São as primeiras células a atuarem contra uma lesão dos vasos sanguíneos. São fragmentações citoplasmáticas dos megacariócitos (células precursoras) originados na medula óssea, anucleadas, com diâmetro de 1 a $4 \mu \mathrm{m}$. Seus índices 
em adultos normais variam de 150.000 até 400.000 por $\mathrm{mm}^{3}$ de sangue (GUYTON, 2006; STEVENS; LOWE, 1995);

d) plasma: é composto em grande parte por água, proteínas (albumina, globulina, entre outras), sais inorgânicos (principalmente cloreto de sódio), entre outras substâncias orgânicas dissolvidas, como aminoácidos, vitaminas, lípides e glicose. A principal função do plasma é transportar nutrientes e metabólitos, assim como as células citadas acima (GUYTON, 2006; STEVENS; LOWE, 1995).

\subsubsection{Leucócitos}

O corpo humano está exposto diariamente a diversos agentes patogênicos, muitos destes causadores de doenças humanas. No entanto, o homem possui um sistema para combater os diferentes agentes infecciosos e tóxicos. Este mecanismo de defesa é formado pelos leucócitos, pelo sistema de macrófagos dos tecidos e pelo tecido linfóide, os quais destroem os agentes invasores, principalmente por meio da fagocitose e pela formação de anticorpos e linfócitos sensibilizados (GUYTON, 2006).

Os leucócitos são subdivididos em polimorfonucleares ou granulócitos e mononucleares, num total de cinco tipos celulares encontrados no sangue em diferentes proporções.

\subsubsection{Polimorfonucleares}

Os neutrófilos quando maturos, apresentam entre 12 e $14 \mu \mathrm{m}$ de diâmetro, núcleo composto por 2 a 5 lóbulos e citoplasma acidófilo com granulações finas de coloração rósea. Estas células compõem em torno de 40 a $75 \%$ dos leucócitos totais circulantes, em condições normais. Mieloblastos são suas células precursoras e sua maturação leva em torno de 7 a 8 dias até transformar-se em neutrófilo, passando por diferentes estágios. Sua vida média em 
circulação no sangue é de 6 horas, depois migram randomicamente para os tecidos periféricos, onde sobrevivem de 2 a 5 dias. Os neutrófilos são os primeiros a atuar na defesa celular contra micro-organismos invasores, através de suas propriedades, como motilidade, quimiotaxia, fagocitose, ação bactericida e digestão de micro-organismos. São células altamente móveis e ao penetrarem nos tecidos podem iniciar a fagocitose imediatamente. Apresentam também papel central nos estágios iniciais da resposta inflamatória aguda à lesão tecidual, devido à rápida velocidade de migração (GUYTON, 2006; STEVENS; LOWE, 1995).

Eosinófilos visualizados em esfregaços de sangue possuem de 12 a $17 \mu \mathrm{m}$ de diâmetro, o núcleo é bilobado e os grânulos são grandes. O número destas células circulantes é de aproximadamente 5\%, apresentando uma variação entre o período da manhã (taxa máxima) e o período da tarde (taxa mínina). Também se originam na medula óssea, divergindo nos estágios seguintes ao mieloblasto. Em geral, deixam a circulação em 3 a 8 horas, permanecendo em torno de 12 dias nos tecidos. São células móveis capazes de fagocitar e estão envolvidas em infecções parasitárias e processos imunológicos, modulando reações alérgicas. Porém, sua ação microbicida é inferior aos neutrófilos. Eles executam suas funções de defesa liberando enzimas hidrolíticas e a proteína básica principal de seus grânulos. Esta proteína é rica em arginina e contribui muito para a acidofilia dos grânulos desta célula, além disso, é tóxica a parasitas humanos e causam a sua morte. Provavelmente, também atuam liberando formas de oxigênio reativo, que são letais aos parasitas (GUYTON, 2006; STEVENS; LOWE, 1995).

Os basófilos são encontrados em pequenas quantidades no sangue periférico, compõem aproximadamente de 0 a $1 \%$ dos leucócitos, possuem de 14 a $16 \mu \mathrm{m}$ de diâmetro, o núcleo raramente tem mais de dois lóbulos, apresentam grandes grânulos citoplasmáticos ricos em histamina e heparina. Como os granulócitos anteriores, os basófilos são produzidos na medula óssea e diferem a partir do estágio de mieloblasto. Atuam principalmente em reações alérgicas de hipersensibilidade imediata, podendo causar anafilaxia, rinite alérgica, urticária e algumas formas de asma (GUYTON, 2006; STEVENS; LOWE, 1995). 


\subsubsection{Mononucleares}

Os linfócitos são encontrados no sangue na proporção de 20 a 50\% dos leucócitos, sendo a maioria de linfócitos pequenos e em porcentagem menores de linfócitos grandes, com diâmetro entre 6 a $15 \mu \mathrm{m}$. Caracterizam-se por apresentarem citoplasma escasso, núcleo com cromatina muito condensada e nucléolos, sendo estes raramente visualizados. Existem dois tipos principais de linfócitos, o $\mathrm{T}$ e o $\mathrm{B}$, ambos ligados ao sistema imune, mas com funções distintas. Os dois tipos são indistinguíveis em esfregaços (GUYTON, 2006; STEVENS; LOWE, 1995).

O linfócito $\mathrm{T}$ origina-se nas células precursoras da medula óssea e sua maturação ocorre no timo. Constituem 70 a $80 \%$ dos linfócitos totais. São responsáveis pela resposta imune mediada por células e regulam a síntese de anticorpos através da secreção de interleucinas. Os linfócitos T "helper" caracterizam-se por apresentar CD4 ("cluster differentiation") como principal molécula marcadora da superfície desta célula. São responsáveis por induzir as células B a produzirem anticorpos e ativar os sistemas de defesa dos macrófagos. Em resposta a estímulos antigênicos, os linfócitos T "helper" secretam citocinas, as quais estimulam a proliferação e diferenciação de linfócitos T e B, entre outras células. Já os linfócitos $\mathrm{T}$ citotóxicos expressam na membrana o marcador CD8 e atuam diretamente nas células alvos, levando à morte as células infectadas por vírus, células tumorais e, ainda, atuam na rejeição de transplantes. A terceira população de linfócitos é chamada de "natural killer" (NKs), cujos marcadores celulares são CD56 e CD57. Estas células também provocam a morte das células infectadas por vírus e células tumorais. No entanto, estão mais envolvidas com o sistema imune inato (ABBAS; LICHTMAN, 2005; GUYTON, 2006; STEVENS; LOWE, 1995).

Os linfócitos B compõem de 15 a $20 \%$ dos linfócitos totais, caracterizam-se por apresentarem imunoglobulinas (Ig) de superfície. Os marcadores de membrana mais usados no seu reconhecimento são CD19 e CD20. Estas células atuam na imunidade humoral, sintetizando e secretando anticorpos após sua diferenciação em plasmócitos. São chamados de células de memória, onde a exposição subsequente ao mesmo antígeno acelera e aumenta a resposta de anticorpos (ABBAS; LICHTMAN, 2005; GUYTON, 2006; STEVENS; LOWE, 1995). 
Os monócitos compreendem 1 a 5\% dos leucócitos totais. São células grandes com diâmetro entre 15 e $18 \mu \mathrm{m}$, formadas na medula óssea. Em esfregaços sangüíneos, assemelham-se aos linfócitos, porém são maiores em tamanho. O núcleo é chanfrado, a cromatina é mais frouxa e o citoplasma é claro. Na ultraestrutura, o citoplasma contém numerosos pequenos grânulos e vacúolos citoplasmáticos, não visualizados nos linfócitos. A membrana celular apresenta numerosas projeções citoplasmáticas, típicas de células fagocitárias. Encontram-se circulantes no sangue por 10 a 20 horas. Após, atravessam as membranas em direção aos tecidos, onde os monócitos passam por transformações para tornarem-se macrófagos. Respondem quimiotaticamente à presença de material necrótico, micro-organismos invasores e à inflamação. Integram a imunidade humoral e celular, dando início à resposta imune como células apresentadoras de antígenos (APC), além de participarem ativamente da fagocitose (ABBAS; LICHTMAN, 2005; GUYTON, 2006; STEVENS; LOWE, 1995). 


\subsection{Interações Vírus e Célula Hospedeira}

Diversos vírus entram em células hospedeiras para sobreviver, replicar e evadir o sistema imune. Os estágios iniciais de uma infecção viral incluem a adsorção, contato entre um receptor celular e uma proteína viral, penetração, perda da cápside viral e liberação do conteúdo genômico. Em geral, estes agentes patogênicos utilizam vias celulares existentes, como as designadas para transporte de nutrientes, que frequentemente terminam seus percursos em lisossomos, organelas capazes de matar micro-organismos. Notavelmente, estes patógenos tem desenvolvido meios de evitar interações com estas organelas (GRUENBERG; VAN DER GOOT, 2006).

Várias famílias virais utilizam a endocitose para infectar as células hospedeiras, facilitando a internalização das partículas virais e o transporte até o sítio de replicação. Estudos recentes demonstram que os vírus utilizam todas as capacidades endocíticas das células, ampliando suas chances de sucesso na infecção dos organismos hospedeiros. As vias endocíticas utilizadas incluem a endocitose mediada pela clatrina e caveolina, macropinocitose e novas vias alternativas independentes de clatrina ou caveolina (Fig. 4). Contudo, nesta última via os mecanismos de internalização permanecem pouco esclarecidos, devido à ausência de informações específicas e marcadores celulares (SIECZKARSKI; WHITTAKER, 2002). O transporte vesicular intracelular de macromoléculas denominado transcitose é uma estratégia utilizada pelos organismos multicelulares para mobilizar material entre dois compartimentos, sem alterar as composições únicas dos mesmos (TUMA; HUBBARD, 2003), podendo ser uma via conveniente para os vírus alcançarem o núcleo da célula infectada.

A endocitose mediada por clatrina é a rota mais conhecida de entrada viral. Através de um sinal de internalização, a clatrina é montada internamente na membrana plasmática para formar vesículas de clatrina ou invaginações. Durante o processo, a clatrina interage com diversas moléculas, como a dinamina GTPase, responsável por liberar as vesículas internalizadas pela membrana plasmática. As vesículas cobertas por clatrina (CCV) seguem para os endossomos precoces dependentes da proteína Rab5. Estes endossomos podem ser reciclados para superfície celular, com auxílio de Rab4 e Rab11, ou seguir para endossomos 
tardios/lisossomos, que necessitam da proteína Rab7 (Fig. 4) (SIECZKARSKI; WHITTAKER, 2002).

A endocitose mediada pela caveolina ocorre por estímulos celulares, com uma cinética de internalização mais lenta quando comparada com a clatrina (Fig. 4). Já a macropinocitose é considerada um mecanismo de internalização não específico, onde, inicialmente, o processo ocorre por uma perturbação dirigida contra actina celular, semelhante ao sistema de fagocitose realizado pelas células especializadas do sistema imune (Fig. 4). Além disso, a macropinocitose não depende de receptores ligantes específicos (SIECZKARSKI; WHITTAKER, 2002).

Os primeiros eventos da infecção pelo papilomavírus, como a ligação e entrada em células susceptíveis, podem fornecer importantes ferramentas para o controle da disseminação deste vírus. Contudo, até o momento, existem controvérsias sobre a natureza precisa do receptor celular para entrada do HPV na célula hospedeira.

A literatura científica descreveu o HPV16 como um vírus altamente espécie e tecidoespecífico, com o requerimento de heparan sulfato extracelular como condição básica à infecção celular, fato este que restringe sua infectividade às células basais do epitélio (GIROGLOU et. al., 2001; JOYCE et. al., 1999). As moléculas de heparan sulfato estão associadas à superfície celular e matriz extracelular de uma grande variedade de células e tecidos. Estas moléculas apresentam elevada capacidade de interações entre fatores de crescimento e seus receptores. É provável que a alta afinidade exibida pela proteína L1 do HPV com heparan sulfato, in vitro, ocorra devido à porção carboxy-terminal exposta na superfície de L1. Esta região apresenta-se bem conservada com sequências muito similares a proteínas, que, conhecidamente, se ligam ao heparan sulfato (JOYCE et. al., 1999). Assim como acontece com outros vírus, ao que parece, o HPV exige a presença de receptores secundários para uma infecção eficiente, e sugeriu-se que este papel pudesse ser desempenhado pela $\alpha 6$ integrina (MCMILLAN et al., 1999).

Recentemente, descobriu-se que o HPV infecta células numa via endocítica mediada por receptor e dependente de clatrina (DAY et. al., 2003), onde suas partículas são internalizadas por uma cinética mais lenta quando comparada com outros vírus de estruturas similares (CULP; CHRISTENSEN, 2004). No entanto, esta via pode não ser conservada para todos os tipos de HPVs. Aparentemente o HPV31 pode entrar via caveolina (BOUSARGHIN et. al., 2003). 
O ferro está presente em muitos processos essenciais tanto para a célula hospedeira quanto para seus patógenos como, por exemplo, a síntese de DNA. No momento em que o ferro é absorvido pela célula, alguns vírus aproveitam para infectá-las durante a entrada celular, através da ligação com o receptor de transferrina (TfR), enquanto que outros patógenos virais alteram a expressão de proteínas envolvidas no metabolismo do ferro (DRAKESMITH; PRENTICE, 2008). O ferro é um elemento necessário para a replicação viral. Sendo assim, uma célula com altos níveis deste elemento favorece o próprio vírus.

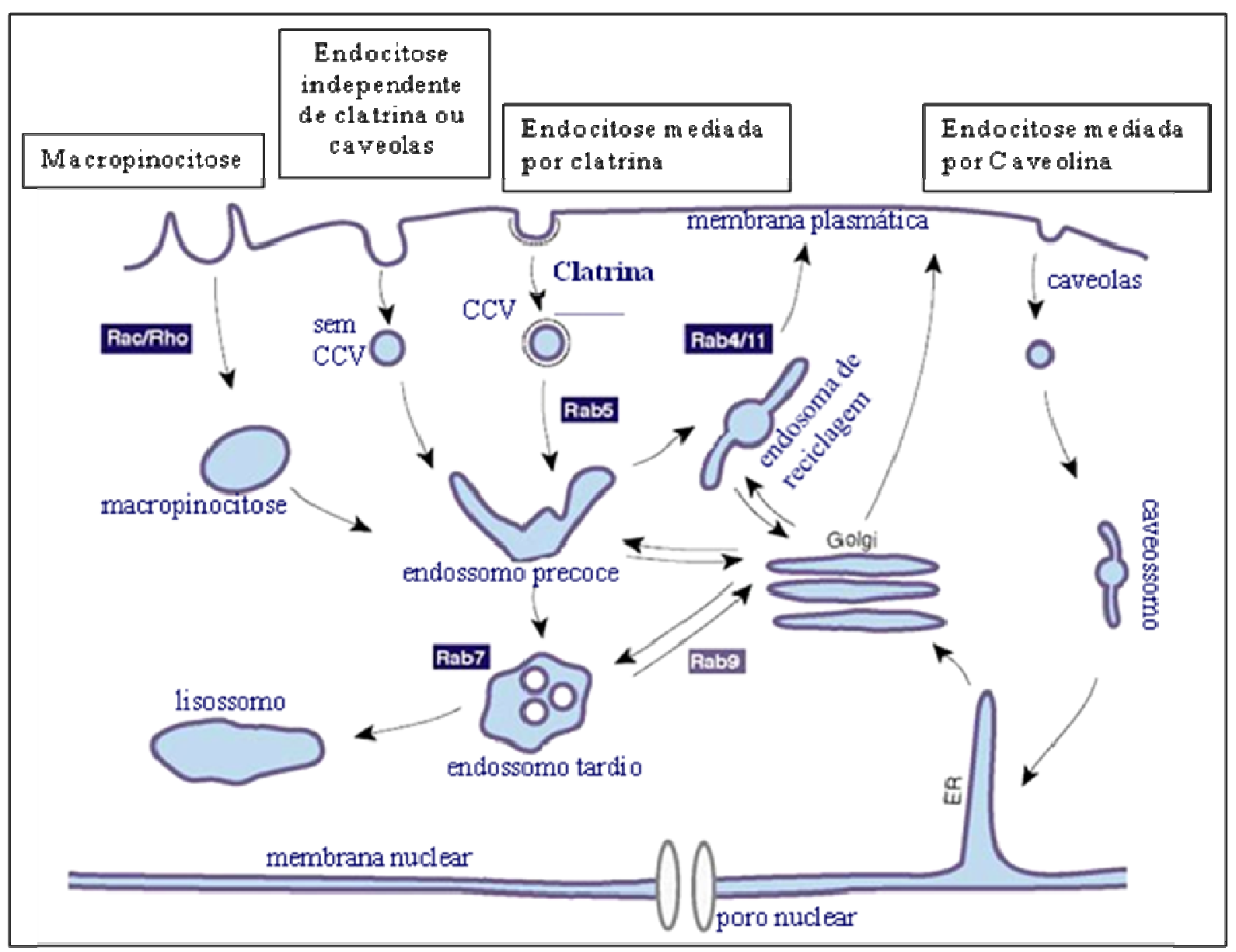

Figura 4: Resumo das principais rotas de endocitose usada por vírus. Adaptado de Sieczkarski e Whittaker, 2002. 
A transferrina (Tf) é uma glicoproteína presente no soro, altamente conservada e mais conhecida por sua capacidade de transportar ferro. Ela circula por todo o organismo, a partir dos locais de absorção, no duodeno e nas células vermelhas do sangue é reciclada por macrófagos, transportando o ferro para todos os tecidos (MACEDO; DE SOUSA, 2008). A Tf pertence a um grupo de proteínas intimamente relacionadas e presentes em todos os vertebrados (YOSHIGA et al., 1997). A Tf humana consiste de uma cadeia polipeptídica contendo 679 aminoácidos. A molécula é composta por dois domínios homólogos entre si, com a sequência N-terminal de 1 a 336 resíduos e a sequência C-terminal de 337 a 679 resíduos. Sua estrutura cristalográfica apresenta dois lóbulos globulares, correspondendo às sequências N- e C-terminais. Cada um dos lóbulos pode ser dividido em dois domínios de tamanhos similares. Em cada um há um sítio de ligação com o ferro, localizado na fissura entre os dois domínios. Durante a captação do ferro e liberação, os domínios sofrem alterações conformacionais causando o fechamento e abertura da fissura. O ferro ligado à Tf é internalizado pelas células expressando o TfR via endocitose mediada por receptor específico. O TfR é um homodímero ligado por ponte dissulfídrica. Em humanos, cada monômero consiste de 760 aminoácidos. Cada monômero possui uma região $\mathrm{N}$-terminal curta, um único domínio transmembranar e uma grande região extracelular glicosilada. O domínio extracelular está diretamente envolvido no processo de ligação com a Tf. Cada monômero pode ligar-se a uma molécula de Tf. O segmento intracelular contém um sítio para fosforilação do receptor desencadeado por ativadores da proteína quinase C. Para diversas proteínas a fosforilação é mecanismo importante de sinalização. Entretanto, a fosforilação do TfR não parece desempenhar um papel importante na endocitose, pois mutações na fosforilação do TfR não impedem a internalização da Tf. O TfR é altamente expresso na superfície de células normais e neoplásicas em proliferação, células precursoras eritrocitárias e em células da placenta, assim como está presente em moderada expressão nas células dos demais tecidos. O TfR é também muito importante na divisão celular dos linfócitos (MACEDO; DE SOUSA, 2008). Sendo o ferro um nutriente indispensável para a divisão celular, a Tf e o TfR tem sido usados como alvos terapêuticos, principalmente na terapia do câncer e diagnósticos em inflamação (LI; QUIAN, 2002; MACEDO; DE SOUSA, 2008; PARDRIDGE, 2007; SAHOO et al., 2004; XIA et al., 2007; ZHANG et al., 2008).

Talvez o Papilomavírus possa utilizar a via endocítica do ferro e a transcitose para infectar células hospedeiras do sangue periférico, através da Tf e do TfR, antecedendo o 
contato com os tecidos-alvo das transformações celulares e do desenvolvimento do câncer anogenital, permanecendo no organismo na forma latente. No momento oportuno, alcançaria o epitélio através da circulação. Após a replicação viral, um número mais expressivo de partículas seria liberado, assim como, transmitido a outros organismos hospedeiros.

Nesta hipótese, a possibilidade de o HPV infectar células leucocitárias do sangue periférico, como parece ocorrer com BPV (CAMPO et al., 1992; CARVALHO, 2003; STOCCO DOS SANTOS et al., 1998), torna o contato com sangue contaminado, quer seja acidental ou através de transfusões, ou ainda pela transmissão materno-fetal (ARMBRUSTER-MORAES et al., 1994; BANDYOPADHYAY; CHATTERJII, 2006; JAYASINGHE; GARLAND, 2006; ROMBALDI et al., 2008; SARKOLA et al., 2008), um fator responsável pela propagação desta doença em escala pandêmica, pois está presente nos cinco continentes, com incidência crescente e preocupante.

Diante do exposto, a análise das possíveis vias alternativas de infecção do HPV, assim como das consequências para o organismo irão favorecer o desenvolvimento de formas de combate à doença, beneficiando a Sociedade e a Instituição com a perspectiva de possíveis inovações tecnológicas e educacionais decorrentes desta pesquisa. 


\section{CONCLUSÕES}

* O método de produção de VLPs contendo as proteínas L1 e L2 do HPV16 que implantamos em culturas de células epiteliais humanas da linhagem 293T mostrou-se eficiente, sendo que $85 \%$ das células foram transfectadas e expressaram partículas estruturadas e proteínas L1 e L2 nativas, em quantidades suficientes ao desenvolvimento deste projeto.

As caracterizações morfológicas demonstraram que as células 293T, expressando L1, produziram estruturas semelhantes às VLPs do HPV16, apresentando epítopos conformacionais.

* As VLPs L1L2 do HPV16, produzidas neste estudo, interagiram in vitro com as células 293T não transfectadas, em ensaios de imunofluorescência.

* O método de separação dos leucócitos humanos que desenvolvemos mostrou-se simples, rápido, de baixo custo e eficiente, com preservação da morfologia e viabilidade celular, sobretudo adequado às necessidades desta pesquisa.

Nos ensaios de interação das VLPs produzidas neste estudo e as células leucocitárias do sangue de mulheres voluntárias sadias, tanto as proteínas do capsídeo L1 quanto as VLPs estruturadas interagiram com leucócitos, através da internalização das partículas, comprovado por ensaios de imunofluorescência.

O presente estudo corrobora com o papel dos linfócitos como prováveis sítios de latência para o HPV, assim como veículos de disseminação e transmissão viral.

Demonstramos que as VLPs L1L2 do HPV16 podem utilizar a via endocítica do ferro mediada por clatrina como receptor para entrada em leucócitos periféricos humanos, através do complexo VLPs-Tf-TfR. 
* Estes dados sugerem que o HPV16 pode utilizar a via alternativa de infecção HPV16Tf-TfR, permanecendo de forma latente no interior de leucócitos humanos.

* Este estudo alcançou plenamente os seus objetivos originais e demonstrou que não há um receptor específico para o HPV infectar as células hospedeiras, sendo também utilizada a via endocítica clássica do ferro, a mais difundida entre os vertebrados e no reino animal.

Esta porta de entrada oportunista poderia explicar a propagação crescente e alarmante deste agravo à saúde humana, motivo de preocupação nos sistemas mundiais de saúde pública.

Somados, os resultados desta pesquisa apóiam a hipótese de o HPV infectar células leucocitárias do sangue periférico humano, fato que torna o contato com sangue contaminado, quer seja acidental ou através de transfusões, ou ainda pela transmissão materno-fetal, um dos fatores responsáveis pela propagação desta doença em escala pandêmica, pois está presente nos cinco continentes, com incidência crescente e preocupante.

Este estudo proporcionou o estabelecimento de um modelo experimental in vitro mais próximo possível das condições naturais de infecção pelo HPV16, inédito na literatura científica internacional. 


\section{REFERÊNCIAS BIBLIOGRAFICAS}

ABBAS, A. K.; LICHTMAN, A. H. Cellular and Molecular Immunology. 5 ed. Philadelphia: Elsevier, 2005. 580 p.

ALMEIDA, M. E. Vírus do papiloma humano (HPV) em sangue periférico de mulheres tratadas de câncer de mama e neoplasia intra cervical. 80f. Tese (Doutorado em Ciências) - Escola Paulista de Medicina, Universidade de São Paulo, São Paulo, 2000.

AIRES, K. A.; CIANCIARULLO, A. M.; CARNEIRO, S. M.; VILLA, L .L.; BOCCARDO, E.; PÉREZ-MARTINEZ, G.; PÉREZ-ARELlANO, I.; OLIVEIRA, M. L. S.; HO, P. L. Production of HPV-16 L1 virus-like particles by recombinant Lactobacillus casei. Appl. Environ. Microbiol., v. 72, p. 745-752, 2006a.

AIRES, K. A.; OLIVEIRA, M. L. S.; CIANCIARULlO, A. M.; CARNEIRO, S. M.; CAMPOS, I. B.; VILLA, L. L.; BOCCARDO, E.; PÉREZ-MARTINEZ, G.; HO, P. L. Expression of the HPV-16 L1 major capsid protein in Lactobacillus. In: THE NINTH ANNUAL CONFERENCE ON VACCINE RESEARCH, 2006b, Baltimore. [online] www.nfid.org/conferences/vaccine06.html.

ASHRAFI G. H, HAGHSHENAS, M. R.; MARCHETTI, B.; O'BRIEN, P. M.; CAMPO, M. S. E5 protein of human papillomavirus type 16 selectively downregulates surface HLA class I. Int. J. Cancer, v. 113, p. 276-283, 2005.

ARMBRUSTER-MORAES, E.; IOSHIMOTO, L. M.; LEÃO, E.; ZUGAIB, M. Presence of human papillomavirus DNA in amniotic fluids of pregnant women with cervical lesions. Gynecol. Oncol., v. 54, p. 152-158, 1994.

BAKER, C. C.; PHELPS, W. C.; LINDGREN, L.; BRAUN, M. J.; GONDA, M. A.; HOWLEY, P. M. Structural and transcriptional analysis of human papillomavirus type 16 sequences in cervical carcinoma cell lines. J. Virol., v. 61, p. 962-971, 1987.

BAKER, T. S.; NEWCOMB, W. W.; OLSON, N. H.; COWSERT, L. M.; OLSON, C.; BROWN, J. C. Structures of bovine and human papillomaviruses. Biophys. J., v. 60, p. 1445-1456, 1991.

BANDYOPADHYAY, S.; CHATTERJEE, R. HPV viral load determination during pregnancy as a possible cervical cancer risk. J. Exp. Clin. Cancer Res., v. 25, p. 29-38, 2006.

* De acordo com: 
BAUER, H. M.; HILDESHEIM, A. SCHIFFMAN, M. H., GLASS, A. G., RUSH, B. B.; SCOTT, D. R.; CADELL, D. M.; KURMAN, R. J.; MANOS, M. M. Determinants of genital human papillomavirus infection in low-risk women in Portland, Oregon. Sex. Transm. Dis., v. 20, p. 274-278, 1993.

BAZAN, S. B. Expressão da Proteína L1 do Capasídeo de HPV-16 em Leveduras Metilotróficas. 106f. Tese (Mestrado em Ciências Biológicas - Bioquímica) - Instituto de Química, Universidade de São Paulo, São Paulo, 2007a.

BAZAN, S. B.; AIRES, K. A.; CIANCIARUllO, A. M.; OLIVEIRA, M. L. S.; HO, P. L. Synthesis and assembly of human papillomavirus type 1611 virus-like particles. In: VACCINE CONGRESS., 2007b, Amsterdam. [online] www.vaccinecongress.com.

BAZAN, S. B. CHAVES, A. A. M.; AIRES, K. A.; CIANCIARUllO, A. M.; HO, P. L. Recombinant HPV-16 L1 VLPs expressed in Picchia pastoris display conformational epitopes that hemagglutinate mouse erythrocytes. Int. J. Med. Microbiol., v. 298, p. 3-3, 2008.

BELNAP, D. M.; OLSON, N. H.; CLADEL, N. M.; NEWCOMB, W. W.; BROWN, J. C.; KREIDER, J. W.; CHRISTENSEN, N. D.; BAKER, T. Conserved features in papillomavirus and polyomavirus capsids. J. Mol. Biol., v. 259, p. 249-263, 1996.

BEUKEN, E.; VINK, C.; BRUGGEMAN, C. A. One-step procedure for screening recombinant plasmids by size. Biotechniques, v. 24, p. 748-750, 1998.

BEZERRA, A. L. R.; LOPES, A.; SANTIAGO, G. H.; RIBEIRO, K. C. B.; LATORRE, M. R. D. O.; VILLA, L. L. Human papillomavirus as a prognostic factor in carcinoma of the penis: analysis of 82 patients with amputation and bilateral lymphadenectomy. Cancer, v. 91, p. 2315-2321, 2001.

BIBANCOS, M.; CERQUEIRA, O. L. D.; SZULCZEWSKI, V.; CIANCIARULLO, A. M.; FERREIRA, L. C. S. Construção de vacinas de DNA capazes de expressar a oncoproteína E7 do vírus papilomavírus humano tipo 16 geneticamente fusionado a flagelina FlicD de Salmonella entérica sv. Muenchen. In: SEMINÁRIO LATINO-AMERICANO DE TECNOlOGiA DE CUltivo CElulareS, 2., 2006a, São Paulo. Prog. e Res. II SLATCC, São Paulo: IPT, 2006a, p. 89. 
BIBANCOS, M.; PORCHIA, B. F. M. M.; CERQUEIRA, O. L. D.; SZULCZEWSKI, V.; CIANCIARULLO, A. M.; FERREIRA, L. C. S. Purificação-expressão de uma subunidade da oncoproteína E7 do vírus papiloma humano tipo 16 (HPV-16) e produção de anticorpos policlonais específicos. In: CONGRESSO BRASILEIRO DE GENÉTICA, 52; CONGRESSO DA ASSOCIAÇÃO LATINO-AMERICANA DE GENÉTICA, 12., 2006b, Foz do Iguaçu. Anais do $52^{\circ}$ Congresso Brasileiro de Genética. Ribeirão Preto: Sociedade Brasileira de Genética, 2006b. p. 817.

BJORGE, T.; ENGELAND, A.; LUOSTARINEN, T.; MORK, J.; GISLEFOSS, R. E.; JELLUM, E.; KOSKELA, P.; LEHTINEN, M.; PUKKALA, E.; THORESEN, S. O.; DILLNER, J. Human papillomavirus infection as a risk factor for anal and perianal skin cancer in a prospective study. Br. J. Cancer, v. 87, p. 61-64, 2002.

BOCCARDO, E.; VILLA, L. L. Vírus e câncer. In: Brentani, M. M.; Coelho, F. R.; Kowalski, L. P. (Ed. Tecmedd). Bases da Oncologia. São Paulo: Plenum Press, 2003. p. 87-104.

BOULET, G.; HORVATH, C.; VANDEN BROECK, D.; SAHEBALI, S.; BOGERS, J. Human papillomavirus: E6 and E7 oncogenes. Int. J. Biochem. Cell Biol., v. 39, p. 20062011, 2007.

BOSCH, F. X.; LORINCZ, A.; MUÑOZ, N.; MEIJER, C. J. L. M.; SHAH, K. V. The causal relation between human papillomavirus and cervical cancer. J. Clin. Pathol., v. 55, p. 244$265,2002$.

BOUSARGHIN, L.; TOUZÉ, A.; COMBITA-ROJAS, A. L.; COURSAGET, P. Positively charged sequences of human papillomavirus type 16 capsid proteins are sufficient to mediate gene transfer into target cells via the heparan sulfate receptor. J. Gen. Virol., v. 84, p. 157$164,2003$.

BUCK, C. B.; CHENG, N.; THOMPSON, C. D.; LOWY, D. R.; STEVEN, A. C.; SCHILLER, J. T.; TRUS, B. L. Arrangement of L2 within the papillomavirus capsid. J. Virol., v. 82, p. 5190-5197, 2008.

BURD, EM. Human Papillomavirus and Cervical Cancer. Clin. Microbiol. Rev., v. 16, p.117, 2003.

BUTTERWORTH, C. E.-JR.; HATCH, K. D.; MACALUSO, M.; COLE, P.; SAUBERLICH, H. E.; SOONG, S. J., BORST, M.; BAKER, V. V. Folate deficiency and cervical dysplasia. JAMA., v. 267, p. 528-33, 1992. 
CAMPO, M. S.; JARRETT, W. F.; BARRON, R., O'NEIL, B. W.; SMITH, K. T. Association of bovine papillomavirus type 2 and bracken fern with bladder cancer in cattle. Cancer Res., v. 52, p. 6898-6904, 1992.

CARVALHO, C. Análise da detecção de sequências genômicas dos vírus do papiloma bovino tipos 1, 2 e 4, em segmentos do trato reprodutivo de fêmeas e machos bovinos e gametas. 85 f. Tese (Doutorado em Medicina Veterinária) - Faculdade de Medicina Veterinária e Zootecnia, Universidade de São Paulo, São Paulo, 2003.

CHANDRACHUD, L. M.; GRINDLAY, G. J.; MCGARVIE, G. M. ; O'NEIL, B. W. ; WAGNER, E. R. ; JARRETT, W. F. ; CAMPO, M. S. Vaccination of cattle with the Nterminus of L2 is necessary and sufficient for preventing infection by bovine papillomavirus4. Virology, v. 211, p. 204-208, 1995.

CHEN, X. S.; GARCEA, R. L.; GOLDBERG, I.; CASINI, G.; HARRISON S. C. Structure of small virus-like particles assembled from the L1 protein of human papillomavirus 16. Mol. Cell., v. 5, p. 557-567, 2000.

CHRISTENSEN, N. D., KREIDER, J. W.; DIANGELO, S. L. The open reading frame L2 of cottontail rabbit papillomavirus contains antibody-inducing neutralizing epitopes. Virology, v. 181, p. 572-579, 1991.

CHRISTENSEN, N. D.; DILLNER, J.; EKLUND, C.; CARTER, J. J.; WIPF, G. C.; REED, C. A.; CLADEL, N. M.; GALLOWAY, D. A. Surface conformational and linear epitopes on HPV-16 and HPV-18 L1 Virus-like particles as defined by monoclonal antibodies. Virology, v. 223, p. 174-184, 1996.

CIANCIARULLO, A. M.; BEÇAK, W.; SOARES, M. J. Immunocytochemical mapping of the hemoglobin biosynthesis site in amphibian erythroid cells. Tissue Cell., v. 31, p. 342-348, 1999.

CIANCIARULLO, A. M.; BERTHO, A. L.; SOARES, M. J.; HOSODA, T. M.; NOGUEIRA-SILVA, S.; BEÇAK, W. Haemoglobin biosynthesis site in rabbit embryos erythroid cells. Cell. Biol. Int., v. 27, p. 747-753, 2003 a.

CIANCIARULLO, A. M.; PELAJO-MACHADO, M.; SPRING, H.; BEÇAK, W.; TRENDELENBURG, M. F. Steps in the cellular iron endocytic pathway and the heme synthesis in vertebrates. In: CONGRESSO DA SOCIEDADE BRASILEIRA DE MICROSCOPIA E MICROANÁliSE, 19., 2003b, Caxambú. Acta Microsc. Rio de Janeiro: Sociedade Brasileira de Microscopia, 2003b, p. 403-404. 
CIANCIARULLO, A. M.; SZULCZEWSKI, V.; AIRES, K. A.; BAZAN, S. B.; HO, P. L.; BOCCARDO, E.; VILLA, L. L.; MÜLLER, M.; ARMBRUSTER-MORAES, E. Production of HPV 16 L1 VLP in human cell culture for basic estudies anogenital cancer. In: SÃO PAULO RESEARCH CONFERENCES - CANCER 2007: FROM MOLECULAR BIOlOGY TO TREATMENT, 8., São Paulo. Appl. Cancer Res. São Paulo: Applied Cancer Research, 2007. p. 81-82.

CIANCIARULLO, A. M.; SZULCZEWSKI, V.; AIRES, K. A.; BAZAN, S. B.; HO, P. L.; BOCCARDO, E.; VILLA, L. L.; MÜLLER, M.; ARMBRUSTER-MORAES, E. HPV16 L1 gene expression, proteins synthesis and interaction in human cell culture. In: SIMPÓSIO NACIONAL DE BIOLOGIA MOLECULAR APLICADA À MEDICINA, 9.,2008, São Paulo. Anais do IX Simp Nac Biol Mol Aplic Med. São Paulo: Sociedade Brasileira de Genética, 2008. p. 30.

CID-ARREGUI, A.; JUÁREZ, V.; ZUR HAUSEN, H. A synthetic E7 gene of human papillomavirus type 16 that yields enhanced expression of the protein in mammalian cells and is useful for DNA immunization studies. J. Virol., v. 77, p. 4928-4937, 2003.

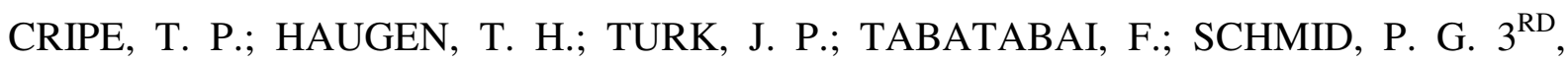
DÜRST, M.; GISSMANN, L.; ROMAN, A.; TUREK, L. P. Transcriptional regulation of the human papillomavirus-16 E6-E7 promoter by a keratinocyte-dependent enhancer, and by viral E2 trans-activator and repressor gene products: implications for cervical carcinogenesis. EMBO J., v. 6, p. 3745-3753, 1987.

CULP, T. D.; CHRISTENSEN, N. D. Kinetics of in vitro adsorption and entry of papillomavirus virions. Virology, v. 319, p. 152-161, 2004.

CUTTS, F. T.; FRANCESCHI, S.; GOLDIE S.; CASTELLSAGUE, X.; DE SANJOSE, S.; GARNETT, G.; EDMUNDS, W. J.; CLAEYS, P.; GOLDENTHAL, K. L.; HARPER, D. M.; MARKOWITZ, L. Human papillomavirus and HPV vaccines: a review. Bull World Health Organ., v. 85, p. 719-726, 2007.

DA SILVA, D. M.; VELDERS, M. P.; NIELAND, J. D.; SCHILLER, J. T.; NICKOLOFF, B. J.; KAST, W. M. Physical interaction of human papillomavirus virus-like particles with immune cells. Int. Immunol., v. 13, p. 633-641, 2001.

DAY, P. M.; LOWY, D. R.; SCHILLER, J. T. Pappilomaviruses infect cells via a clathrindependent pathway. Virology, v. 307, p. 1-11, 2003. 
DE VILLIERS, E. M.; FAUQUET, C.; BROKER, T. R.; BERNARD, H. U.; ZUR HAUSEN, H. Classification of papillomaviruses. Virology, v. 324, p. 17-27, 2004.

DRAKESMITH, H.; PRENTICE, A. Viral infection and iron metabolism. Nat. Rev. Microbiol., v. 6, p. 541-552, 2008.

EMBERS, M. E.; BUDGEON, L. R.; PICKEL, M. CHRISTENSEN, N. D. Protective immunity to rabbit oral and cutaneous papillomaviruses by immunization with short peptides of L2, the minor capsid protein. J. Virol., v. 76, p. 9798-9805, 2002.

FLORIN, L.; SAPP, C.; STREECK, R. E.; SAPP, M. Assembly and translocation of papillomavirus capsid proteins. J. Virol., v. 76, p. 10009 - 10014, 2002a.

FLORIN, L.; SCHAFER, F.; SOTLAR, K.; STREECK, R. E.; SAPP, M. Reorganization of nuclear domain 10 induced by papillomavirus capsid protein 12. Virology, v. 295, p. 97-107, $2002 b$.

FOTHERGILL, T.; MCMILLAN, N. A. J. Papillomavirus virus-like particles activate the PI3-kinase pathway via alpha-6 beta-4 integrin upon binding. J. Virol., v. 352, p. 319-328, 2006.

FRANCO, E. L. Viral etiology of cervical cancer: a critique of the evidence. Rev. Infect. Dis., v. 13, p. 1195-1206, 1991.

FRANCO, E. L.; DUARTE-FRANCO, E.; FERENCZY, A. Cervical cancer: epidemiology, prevention and the role of human papillomavirus infection. CMAJ., v. 164, p. 1017-1025, 2001.

FAVRE, M. S.; MAJEWSKI, N. J.; MALEJCZYK, M.; ORTH, G.; JABLONSKA, S. A possible vertical transmission of human papillomavirus genotypes associated with epidermodysplasia verruciformis. J. Investig. Dermatol., v. 111, p. 333-336, 1998.

FREGA, A.; CENCI, M.; STENTELLA, P.; CIPRIANO, L.; DE IORIS, A.; ALDERISIO, M.; VECCHIONE, A. Human papilllomavirus in virgins and behaviour at risk. Cancer Lett., v. 194, p. 21-24, 2003.

GHIM, S. J.; JENSON, A. B.; SCHLEGEL, R. HPV-1 L1 protein expressed in cos cells displays conformational epitopes found on intact virions. Virology, v. 190, p. 548- 552, 1992. 
GIROGLOU, T.; FLORIN, L.; SCHÄFER, F.; STREECK, R. E.; SAPP, M. Human papillomavirus infection requires cell surface heparan sulfate. J. Virol., v. 75, p. 1565-1570, 2001.

GNANAMONY, M.; PEEDICAYIL, A.; ABRAHAM, P. An overview human papillomaviruses and current vaccines strategies. Indian J. Med. Microbiol., v. 25, p.10-17, 2007.

GOODWIN, E. C.; DIMAIO, D. Repression of human papillomavirus oncogenes in HeLa cervical carcinoma cells causes the orderly reactivation of dormant tumor suppressor pathways. Proc. Natl. Acad. Sci. USA, v. 97, p. 12513-12518, 2000.

GRUENBERG, J.; VAN DER GOOT, F. G. Mechanisms of pathogen entry through the endosomal compartments. Nat. Ver. Mol. Cell Biol., v. 7, p. 495-504, 2006.

GUYTON, A. C. Tratado de Fisiologia Médica. 11.ed. Rio de Janeiro: Elsevier, 2006. 1115 p.

HANAHAN, D. Studies on transformation of Escherichia coli with plasmid. J. Mol. Biol., v. 166, p. 557-579, 1983.

HARPER, D. M. et al. Sustained efficacy up to 4.5 years of a bivalent L1 virus-like particle vaccine against human papillomavirus types 16 and 18: follow-up from a randomised control trial. Lancet, v. 367, p. 1247-1255, 2006.

HEBNER, C. M.; LAIMINS, L. A. Human papillomaviruses: basic mechanisms of pathogenesis and oncogenicity. Rev. Med. Virol., v. 16, p. 83-97, 2006.

HEILMAN, S. A.; NORDBERG, J. J.; LIU, Y.; SLUDER, G.; CHEN, J. J. Abrogation to the postmitotic checkpoint contributes to polyploidization in HPV E7 expressing cells. J. Virol., 2009. In press.

HEMMINKI, K.; DONG, C.; VAITTINEN, P. Second primary cancer after in situ and invasive cervical cancer. Epidemiology, v. 11, p. 457-461, 2000. 
HERMONAT, P. L.; HAN, L.; WENDEL, P. J.; QUIRK, J. G.; STERN, S.; LOWERY, C. L.; RECHTIN, T. M. Human papillomavirus is more prevalent in first trimester spontaneously aborted products of conception compared to elective specimens. Virus Genes., v. 14, p. 1317, 1997.

HILDESCHEIM, A. et al. Determinants of genital human papillomavirus infection in lowincome women in Washington, D.C. Sex. Transm. Dis., v. 20, p. 279-285, 1993.

HINDMARSH, P. L.; LAIMINS, L. A. Mechanisms regulating expression of the HPV 31 L1 and L2 capsid proteins and pseudovirion entry. Virol. J., v. 4, p. 1-12, 2007.

HO, G. Y., BURK, R. D.; FLEMING, I.; KLEIN, R. S. Risk of genital human papillomavirus infection in women with human immunodeficiency virus-induced immunosuppression. Int. J. Cancer, v. 56, p. 788-792, 1994.

HOLMGREN, S. C.; PATTERSON, N. A.; OZBUN, M. A.; LAMBERT, P. F. The minor capsid protein L2 contributes to two steps in the human papillomavirus type 31 life cycle. J. Virol., v. 79, p. 3938-3948, 2005.

INSINGA, R. P.; DASBACH, E. J.; ELBASHA, E. H. Assessing the annual economic burden of preventing and treating anogenital human papillomavirus-related disease in the US: analytic framework and review of the literature. Pharmacoeconomics, v. 23, p. 1107-1122, 2005.

INSTITUTO NACIONAL DO CÂNCER. Estimativa 2008: INCIDÊNCIA DE CÂNCER NO BRASIL. Rio de Janeiro: INCA, 2007. 96 p.

JAYASINGHE, Y.; GARLAND, S. M. Genital warts in children: what do they mean? Arch. Dis. Child., v. 91, p. 696-700, 2006.

JOYCE, J. G.; TUNG, J. S.; PRZYSIECKI, C. T.; COOK, J. C.; LEHMAN, F. D.; SANDS, J. A.; JANSEN, K. U.; KELLER, P. M. The L1 major capsid protein of human papillomavirus type 11 recombinant virus-like particles interacts with heparin and cell-surface glycosaminoglycans on human keratinocytes. J. Biol. Chem., v. 274, p. 5810-5822, 1999.

KARAS, Z.; POREBA, E. HPV sequences in blood of patients with condyloma acuminata. J. Invest. Dermatol., v. 110, p. 843-844, 1998. 
KAWANA, Y.; KAWANA, K.; YOSHIKAWA, H.; TAKETANI, Y.; YOSHIIKE, K.; KANDA, T. Human papillomavirus type 16 minor capsid protein $12 \mathrm{~N}$-terminal region containing a common neutralization epitope binds to the cell surface and enters the cytoplasm. J. Virol., v. 75, p. 2331-2336, 2001.

KIEBACK, E.; MÜLLER, M. Factors influencing subcellular localization of the human papillomavirus L2 minor structural protein. Virology, v. 345, p, 199-208, 2006.

KIRNBAUER, R.; BOOY, F.; CHENG, N.; LOWY, D. R.; SCHILLER, J. T. Papillomavirus L1 major capsid protein self-assembles into virus-like particles that are highly immunogenic.

Proc. Natl. Acad. Sci. USA, v. 89, p. 12180-12184, 1992.

KUCK, D.; LAU, T.; LEUCHS, B.; KERN, A.; MÜLLER, M.; GISSMANN, L.; KLEINSCHMIDT, J. A. Intranasal vaccination with recombinant adeno-associated virus type 5 against human papillomavirus type 16 L1. J. Virol., v. 80, p. 2621-2630, 2006.

LEDER, C.; KLEINSCHMIDT, J. A.; WIETHE, C.; MÜLLER, M. Enhancement of Capsid Gene Expression: Preparing the Human Papillomavirus Type 16 Major Structural Gene L1. J. Virol., v. 75, p. 9201-9209, 2001.

LI, H.; QIAN, Z. M. Transferrin/transferrin receptor-mediated drug delivery. Med. Res. Rev., v. 22, p. 225-250, 2002.

LIU, X. S.; ABDUL-JABBAR, I.; QI, Y. M.; FRAZER, I. H.; ZHOU, J. Mucosal immunisation with papillomavirus virus-like particles elicits systemic and mucosal immunity in mice. Virology, v. 252, p. 39-45, 1998.

MACEDO, M. F.; DE SOUSA, M. Transferrin and the transferrin receptor: of magic bullets and other concerns. Inflamm. Allergy Drug Targets, v. 7, p. 41-52, 2008.

MATORRAS, R.; ARICETA, J. M.; REMENTERIA, A.; CORRAL, J.; GUTIERREZ DE TERÁN, G.; DIEZ, J.; MONTOYA, F.; RODRIGUEZ-ESCUDEIRO, F. J. Human immunodeficiency virus-induced immunosuppression: a risk factor for human papillomavirus infection. Am. J. Obstet. Gynecol., v. 164, p. 42-44, 1991.

MCLAUGHLIN-DRUBIN, M. E.; BROMBERG-WHITE, J. L.; MEYERS, C. The role of the human papillomavirus type 18 E7 oncoprotein during the complete viral life cycle. Virology, v. 338, p. 61-68, 2005. 
MCMILLAN, N. A.; PAYNEA, E.; FRAZER, I. H.; EVANDERB, M. Expression of the alpha6 integrin confers papillomavirus binding upon receptor-negative B-cells. Virology, v. 261, p. 271-279, 1999.

MODIS, Y.; TRUS, B. L.; HARRISON, S. C. Atomic model of the papillomavirus capsid. EMBO J., v. 21, p. 4754-4762, 2002.

MOSSADEGH, N.; GISSMANN, L.; MÜLLER, M.; ZENTGRAF, H.; ALONSO, A.; TOMAKIDI, P. Codon optimization of the human papillomavirus 11 (HPV 11) L1 gene leads to increased gene expression and formation of virus-like particles in mammalian epithelial cells. J. Virol., v. 326, p. 57-66, 2004.

MÜLLER, M.; GISSMANN, L.; CRISTIANO, R. J.; SUN, X. Y.; FRAZER, I. H.; JENSON, A. B.; ALONSO, A. ZENTGRAF, H.; ZHOU, J. Papillomavirus capsid binding and uptake by cells from different tissues and species. J. Virol., v. 69, p. 948-954, 1995.

MÜllER, M.; ZHOU, J.; REED, T. D.; RITTMÜLlER, C.; BURGER, A.; GABELSBERGER, J. BRASPENNING, J.; GISSMANN, L. Chimeric papillomavirus-like particles. Virology, v. 234, p. 93-111, 1997.

MÜLLER, M. Human Papilloma Viruses: Methods and Protocols. Humana Press Inc. In: DAVY, C.; DOORBAR, J. Methods in Molecular Medicine. v. 119. Totowa, NJ. 2005. cap. 31, p. 435-446.

MUNÕZ, N.; CASTEllSAGUÉ, X.; DE GONZALEZ, A. B.; GISSMANN, L. Chapter 1: HPV in the etiology of human cancer. Vaccine, v. 24S3, p. S3/1-S3/10, 2006.

NARDELLI-HAEFLIGER， D.; RODEN， R. B.; BENYACOUB， J. SAHLI, R. KRAEHENBUHL, J. P.; SCHILLER, J. T.; LACHAT, P.; POTTS, A.; DE GRANDI, P. Human papillomavirus type 16 virus-like particles expressed in attenuated Salmonella typhimurium elicit mucosal and systemic neutralizing antibodies in mice. Infect. Immun., v. 65, p. 3328-3336, 1997.

NONNENMACHER, B.; BREITENBACH, V.; VILLA, L. L.; PROLLA, J. C.; BOZZETTI, M. C. Identificação do papilomavírus humano por biologia molecular em mulheres assintomáticas. Rev. Saúde Pública., v. 36, p. 95-100, 2002.

OZBUN, M. A. Infectious human papillomavirus type 31b: purification and infection of an immortalized human keratinocyte cell line. J. Gen. Virol., v. 83, p. 2753-2763, 2002. 
PAO, C. C.; LIN, S. S.; LIN, C. Y.; MAA, J. S.; LAI, C. H.; HSIEH, T. T. Identification of human papillomavirus DNA sequences in peripheral blood mononuclear cells. Am. J. Clin. Pathol., v. 95, p. 540-546, 1991.

PARDRIDGE, W. M. Drug targeting to the brain. Pharm. Res., v. 24, p. 1733-1744, 2007.

PASTRANA, D. V.; GAMBHIRA, R.; BUCK, C. B.; PANG, Y. Y.; THOMPSON, C. D.; CULP, T. D.; CHRISTENSEN, N. D.; LOWY, D. R.; SCHILLER, J. T.; RODEN, R. B. Cross-neutralization of cutaneous and mucosal Papillomavirus types with anti-sera to the amino terminus of L2. Virology. v. 337, p. 365-372, 2005.

PAWELEC, G.; KOCH, S.; FRANCESCHI, C.; WIKBY, A. Human immunosenescence does it have an infectious component? Ann. N.Y. Acad. Sci., v. 1067, p. 56-65, 2002.

PAYNE, D.; TYRING, S. K.; DOHERTY, M. G.; DAYA, D.; CHAN, T. S. Detection of human papillomavirus type 16 in plasma cells. Gynecol. Oncol., v. 48, p. 406-412, 1993.

PENG, S.; JI, H.; TRIMBLE, C.; TSAI, Y. C.; YEATERMEYER, J.; BOYD, D. A.; HUNG, C. F.; WU, T. C. Development of a DNA vaccine targeting human papillomavirus type 16 oncoprotein E6. J. Virol., v. 78, p. 8468-8476, 2004.

PURANEN, M. H.; YLISKOSKI, M. H.; SAARIKOSKI, S. V.; SYRJÄNEN, K. J.; SYRJÄNEN, S. M. Exposure of an infant to cervical human papillomavirus infection of the mother is common. Am. J. Obstet. Gynecol., v. 176, p. 1039-1045, 1997.

PYEON, D.; LAMBERT, P. F.; AHLQUIST, P. Production of infectious human papillomavírus independently of viral replication and epithelial cell differentiation. Proc. Natl. Acad. Sci. USA, v. 102, p. 9311-9316, 2005.

RABELLO-SANTOS, S. H.; ZEFERINO, L. ; VILLA, L. L.; SOBRINHO, J. P.; AMARAL, R. G.; MAGALHÃES, A. V. Human papillomavirus prevalence among women with cervical intraepithelial neoplasia III and invasive cervical cancer from Goiânia, Brazil. Mem. Inst. Oswaldo Cruz., v. 98, p. 181-184, 2003.

REUTER, J. D.; VIVAS-GONZALES, B. E. ; GOMEZ, D. ; WILSON, J. H.; BRANDSMA, J. L.; GREENSTONE, H. L.; ROSE, J. K.; ROBERTS, A. Intranasal vaccination with a recombinant vesicular stomatitis virus expressing cottontail rabbit papillomavirus L1 protein provides complete protection against papillomavirus-induced diseases. J. Virol., v. 76, p. 8900-8909, 2003. 
RODEN, R. B.; KIRNBAUER, R.; JENSON, A. B.; LOWY, D. R.; SCHILLER, J. T. Interaction of papillomaviruses with the cell surface. J. Virol., v. 68, p. 7260-7266, 1994a.

RODEN, R. B.; WEISSINGER, E. M.; HENDERSON, D. W.; BOOY, F.; KIRNBAUER, R.; MUSHINSKI, J. F.; LOWY, D. R.; SCHILLER, J. T. Neutralization of bovine papillomavirus by antibodies to L1 and L2 capsid proteins. J. Virol., v. 68, p. 7570-7574, 1994 b.

RODEN, R. B.; DAY, P. M.; BRONZO, B. K.; YUTZY, W. H. IV; YANG, Y.; LOWY, D. R.; SCHILLER, J. T. Positively charged termini of the L2 minor capsid protein are necessary for papillomavirus infection. J. Virol., v.75, p. 10493-10497, 2001.

RODEN, R. B.; LING, M.; WU, T. C. Vaccination to prevent and treat cervical cancer. Hum. Pathol., v. 35, p. 971-982, 2004.

ROMBALDI, R. L.; SERAFINI, E. P.; MANDELLI, J.; ZIMMERMANN, E.; LOSQUIAVO, K. P. Transplacental transmission of Human Papillomavirus. Virol. J., v. 5, p. 106, 2008.

ROSENFELD, G. Corante pancrômico para hematologia e citologia clínica. Nova combinação de componentes do may-grunwald e do giemsa num só corante de emprego rápido. Mem. Inst. Butantan, v.20, p. 329-335, 1942.

ROUSSEAU, M. C.; VILLA, L. L.; COSTA, M. C.; ABRAHAMOWICZ, M.; ROHAN, T. E.; FRANCO, E. Occurrence of cervical infection with multiple human pappilomavirus types is associated with age and cytologic abnormalities. Sex. Trans. Dis., v. 30, p. 581-587, 2003.

RUBIN, M. A.; KLETER, B.; ZHOU, M.; AYALA, G.; CUBILLA, A. L.; QUINT, W. G. V.; PIROG, E. C. Detection and typing of human papillomavirus DNA in penile carcinoma: evidence for multiple independent pathways of penile carcinogenesis. Am. J. Pathol., v. 159, p. 1211-1218, 2001.

SAAD-HOSSNE, R.; HOSSNE, W. S.; PRADO, R. G. Efeito da solução aquosa de fenol ácido acético e glicerina sobre o tumor de Ehrlich: estudo experimental in vitro. Acta Cir. Bras. v. 1, jan. 2004. Disponível em: [http://www.scielo.br/acb]. Acesso em: 15 out. 2008.

SAHOO, S. K.; MA, W.; LABHASETWAR, V. Efficacy of transferrin-conjugated paclitaxelloaded nanoparticles in a murine model of prostate cancer. Int. J. Cancer., v. 112, p. 335340, 2004. 
SAMBROOK, J.; FRITSCH, E. F.; MANIATS, T. Molecular cloning: a laboratory manual. 2. ed. Plainview: Cold Spring Harbor Laboratory, 1989. 1000 p.

SAPP, M.; VOLPERS, C.; MÜLLER, M.; STREECK, R. E. Organization of the major and minor capsid proteins in human papillomavirus type 33 virus-like particles. J. Gen. Virol., v. 76, p. 2407-2412, 1995.

SARKOLA, M. E.; GRÉNMAN, S. E.; RINTALA, M. A.; SYRJÄNEN, K. J.; SYRJÄNEN, S. M. Human papillomavirus in the placenta and umbilical cord blood. Acta Obstet. Gynecol. Scand., v. 87, p. 1181-1188, 2008.

SASAGAWA, T.; PUSHKO, E. F.; STEERS, G.; GSCHMEISSNER, S. E.; HAJIBAGHERI, M. A., FINCH, J.; CRAWFORD, L.; TOMMASINO, M. Synthesis and assembly of viruslike particles of human papillomaviruses type 6 and type 16 in fission yeast Schizosaccharomyces pombe. Virology, v. 206, p. 126-135, 1995.

SCHIFFMAN, M. H.; BRINTON, L. A. The epidemiology of cervical carcinogenesis. Cancer, v. 76, p. 1888-1901, 1995.

SCHLECHT, N. F.; KULAGA, S.; ROBITAILLE, J.; FERREIRA, S.; SANTOS, M.; MIYAMURA, R. A.; DUARTE-FRANCO, E.; ROHAN, T. E.; FERENCZY, A.; VILLA, L. L.; FRANCO, E. L. Persistent human papillomavirus infection as a predictor of cervical intraepithelial neoplasia. JAMA, v. 286, p. 3106-3114, 2001.

SIECZKARSKI, S. B.; WHITTAKER, G. R. Dissecting virus entry via endocytosis. J. Gen. Virol., v. 83, p. 1535-1545, 2002.

STANLEY, M. Immunobiology of HPV and HPV vaccines. Gynecol. Oncol., v. 109, p. S15S21, 2008.

STEBEN, M.; DUARTE-FRANCO, E. Human papillomavirus infection: Epidemiology and pathophysiology. Gynecol. Oncol., v. 107, p. S2-S5, 2007.

STEGER, G.; CORBACH, S. Dose-dependent regulation of the early promoter of human papillomavirus type 18 by the virail E2 protein. J. Virol., v. 71, p. 50-58, 1997.

STEVENS, A.; LOWE, J. Histologia. 1. ed. São Paulo: Manole, 1995. 378 p. 
STOCCO DOS SANTOS, R. C.; LINDSEY, C. J.; FERRAZ, O. P.; PINTO, J. R.; MIRANDOLA, R. S.; BENESE, F. J.; BIRGEL, E. H.; BRAGANÇA-PEREIRA, C. A.; BEÇAK, W. Bovine papillomavirus transmission and chromosomal aberrations: an experimental model. J. Gen. Virol., v. 79, p. 2127-2135, 1998.

STUBENRAUCH, F.; LAIMINS, L. A. Human papillomavirus life cycle: active and latent phases. Semin. Cancer Biol., v. 9, p. 379-386, 1999.

SUBRAMANYAM, D.; KRISHNA, S. c-Myc substitutes for Notch 1-CBF1 functions in cooperative transformation with papillomavirus oncogenes. Virolology, v. 347, p. 191-198, 2006.

SZULCZEWSKI, V.; KESSLER-PORTO, A. P. A. G.; TROIANO, P. E. R.; SPRING, H.; TRENDELENBURG, M.; PELAJO-MACHADO, M.; BEÇAK, W.; ARMBRUSTERMORAES, E.; CIANCIARULLO, A. M. Expression of HPV-induced proteins in cervical carcinoma cell lines. Mem. Inst. Butantan, v. 63, p. 71, 2006. Apresentado na Reunião Científica do Instituto Butantan, 8, 2006, São Paulo.

SZULCZEWSKI, V.; TROIANO, P. E. R.; CIANCIARULLO, A. M. Method for isolating leukocytes for in vitro assays of pathogen-host cell interaction. Mem. Inst. Butantan, v. 64, p. 39, 2007a. Apresentado na Reunião Científica do Instituto Butantan, 9, 2007, São Paulo.

SZULCZEWSKI, V.; AIRES, K. A.; BAZAN, S. B.; KESSLER-PORTO, A. P. A. G.; PALUMBO, A. C. M.; BENEDETTO, D. M.; SILVA, K. A.; ARMBRUSTER-MORAES, E.; BOCCARDO, E.; VILLA, L. L.; CIANCIARULLO, A. M. HPV oncoproteins, iron endocytic pathway and mitochondria in mammalian cells. In: SÃO PAULO RESEARCH CONFERENCES - CANCER 2007: FROM MOLECULAR BIOLOGY TO TREATMENT, 8., São Paulo. Appl. Cancer Res. São Paulo: Applied Cancer Research, 2007b. p. 37-38.

SZULCZEWSKI, V.; PALUMBO, A. C. M.; SILVA, K. A.; AIRES, K. A.; BAZAN, S. B.; HO, P. L.; BOCCARDO, E.; VILLA, L. L.; ARMBRUSTER-MORAES, E.; CIANCIARULLO, A. M. Human cells mitochondria as target of human papillomaviruses E6 oncoprotein. In: APOPTOSIS WORLD 2008: FROM MECHANISMS TO APPLICATIONS, 2008, Luxemburgo. Proceedings and Program. Luxemburgo: Fondation de Recherche Cancer et Sang, 2008. p. 113.

THOMAS, M., PIM, D., BANKS, L. The role of the E6-p53 interaction in the molecular pathogenesis of HPV. Oncogene, v. 18, p. 7690-7700, 1999. 
TROWBRIDGE, I. S.; OMARY, M. B. Human cell surface glycoprotein related to cell proliferation is the receptor for transferrin. Proc. Natl. Acad. Sci. USA, v.78, p. 3039-3043, 1981.

TSENG, C. J.; LIN, C. Y.; WANG, R. L.; CHEN, L. J.; CHANG, Y. L.; HSIEH, T. T.; PAO, C. C. Possible transplacental transmission of human papillomaviruses. Am. J. Obstet. Gynecol., v. 166, p. 35-40, 1992.

TUMA, P. L.; HUBBARD, A. L. Transcytosis: crossing cellular barriers. Physiol. Rev., v. 83, p. 871-932, 2003.

VILLA, L. L. et al. Prophylactic quadrivalent human papillomavirus (types 6, 11, 16, and 18) L1 virus-like particle vaccine in young women: a randomized double-blind placebo-controlled multicentre phase II efficacy trial. Lancet Oncol., v. 6, p. 271-278, 2005.

VILLA, L. L. et al. Immunologic responses following administration of a vaccine targeting human papillomavirus types 6, 11, 16, and 18. Vaccine, v. 24, p. 5571-5583, 2006a.

VILLA, L. L. et al. High sustained efficacy of a prophylactic quadrivalent human papillomavirus types 6/11/16/18 L1 virus-like particle vaccine through 5 years of follow-up. Br. J. Cancer, v. 95, p. 1459-1466, 2006 b.

WANG, X., ZHU, Q.; RAO, H. Maternal-fetal transmission of human papillomavirus. Chin. Med. J., v. 111, p. 726-727, 1998.

WARZECHA, H.; MASON, H. S.; LANE, C.; TRYGGVESSON, A.; RYBICKI, E.; WILLIAMSON, A. L.; CLEMENTS, J. D.; ROSE, R. C. Oral immunogenicity of human papillomavirus-like particles expressed in potato. J. Virol., v. 77, p. 8702-8711, 2003.

WATT, F. M. Epidermal stem cells: markers, patterning and the control of stem cell fate. Philos. Trans. R. Soc. Lond. B. Biol. Sci., v. 353, p. 831-837, 1998.

WOODMAN, C. B.; COLLINS, S. I.; YOUNG, L. S. The natural history of cervical HPV infection: unresolved issues. Nat. Rev. Cancer, v. 7, p. 11-22, 2007.

WONG, A. K.; CHAN, R. C.; NICHOLS, W. S.; BOSE, S. Invader human papillomavirus (HPV) type 16 and 18 assays as adjuncts to HPV screening of cervical papanicolaou smears with atypical squamous cells of undetermined significance. Cancer, 2009. In press. 
WORLD HEALTH ORGANIZATION. Collaborative Study of Neoplasia and Steroid Contraceptives. Invasive squamous-cell cervical carcinoma and combined oral contraceptives: results from a multinational study. Int. J. Cancer, v. 55, p. 228-36, 1993.

WORLD HEALTH ORGANIZATION. Cervical Cancer Screening in Developing Countries Report of a WHO consultation. França: Inís, 2002, 75 p.

WILSON, R.; FEHRMANN, F.; LAIMINS, L. A. Role of the E1^E4 protein in the differentiation-dependent life cycle of human papillomavirus type 31. J. Virol., v. 79, p. 6732-6740, 2005.

WILSON, V. G.; WEST, M.; WOYTEK, K.; RANGASAMY, D. Papillomavirus E1 proteins: form, function, and features.Virus Genes, v. 24, p. 275-290, 2002.

XIA, C. F.; ZHANG, Y.; ZHANG, Y.; BOADO, R. J.; PARDRIDGE, W. M. Intravenous siRNA of brain cancer with receptor targeting and avidin-biotin technology. Pharm. Res., v. 24, p. 2309-2316, 2007.

XU, S.; LIU, L.; LU, S.; REN, S. Clinical observation on vertical transmission of human papillomavirus. Chin. Méd. Sci. J., v. 13, p. 29-31, 1998.

YOSHIGA, T.; HERNANDEZ, V. P.; FALLON, A. M.; LAW, J. H. Mosquito transferrin, an acute-phase protein that is up-regulated upon infection. Proc. Natl. Acad. Sci. USA, v. 94, p. 12337-12342, 1997.

ZHANG, B.; LI, P.; WANG, E.; BRAHMI, Z.; DUNN, K. W.; BLUM, J. S.; ROMAN, A. The E5 protein of human papillomavirus type 16 perturbs MHC class II antigen maturation in human foreskin keratinocytes treated with interferon-gamma. Virology, v. 310, p. 100-108, 2003.

ZHANG, Y.; WANG, Y.; BOADO, R. J.; PARDRIDGE, W. M. Lysosomal enzyme replacement of the brain with intravenous non-viral gene transfer. Pharm. Res., v. 25, p. 400406, 2008.

ZHOU, J.; STENZEL, D. J.; SUN, X.; FRAZER, I. H. Synthesis and assembly of infectious bovine papillomavirus particles in vitro. J. Gen. Virol., v. 74, p. 763-768, 1993. 
ZIZZADORO, C.; BELLOLI, C.; BADINO, P.; ORMAS, P. A rapid and simple method for the separation of pure lymphocytes from horse blood. Vet. Immunol. Immunopathol., v. 89, p. 99-104, 2002.

ZUCKER-FRANKLIN, D.; GREAVES, M. F.; GROSSI, C. E.; MARMONT, A. M. Atlas of Blood Cells: functions and pathology. 2. ed. Milano: Ermes, 1988, 2 vol.

ZUR HAUSEN, H. Papillomavirus infections: a major cause of human cancers. Biochim. Biophys. Acta, v. 1288, p. F55-F78, 1996.

ZUR HAUSEN, H. Papillomavirus and cancer: from basic studies to clinical application. Nat. Ver. Cancer, v. 2, p. 342-350, 2002. 